This document is the accepted manuscript version of the following article: Bedoya, C. L., Hofstetter, R. W., Nelson, X. J., Hayes, M., Miller, D. R., \& Brockerhoff, E. G. (2021). Sound production in bark and ambrosia beetles. Bioacoustics, 30(1), 58-73. https://doi.org/10.1080/09524622.2019.1686424

\title{
Sound Production in Bark and Ambrosia Beetles
}

\author{
Carol L. Bedoya ${ }^{\mathrm{a},}{ }^{,}$, Richard W. Hofstetter ${ }^{\mathrm{b}}$, Ximena J. Nelson ${ }^{\mathrm{a}}$, Michael Hayes ${ }^{\mathrm{c}}$, Daniel R. Miller ${ }^{\mathrm{d}}$, \\ Eckehard G. Brockerhoffa,e,f. \\ ${ }^{a}$ School of Biological Sciences, University of Canterbury, Private Bag 4800, Christchurch, New Zealand \\ ${ }^{b}$ School of Forestry, Northern Arizona University, Flagstaff AZ, USA \\ ${ }^{c}$ Department of Electrical and Computer Engineering, University of Canterbury, Private Bag 4800, Christchurch, \\ New Zealand; \\ ${ }^{d}$ USDA Forest Service, Southern Research Station, Athens GA, USA \\ ${ }^{e}$ Scion (New Zealand Forest Research Institute), P.O. Box 29237, Christchurch 8540, New Zealand. \\ ${ }^{f}$ Swiss Federal Research Institute WSL, Zürcherstrasse 111, 8903 Birmensdorf, Switzerland. \\ "Corresponding author: CLBedoya.contact@gmail.com, +64220379875.
}

\begin{abstract}
Bark and ambrosia beetles and pinhole borers (Coleoptera: Curculionidae: Scolytinae and Platypodinae) are two subfamilies of weevils that use acoustic communication within plant tissue. These insects transmit and detect sound in a medium that is neither air nor water and they are among the smallest animals with sound-producing organs. Nevertheless, their sound production is sorely understudied, mostly due to the difficulties associated with acoustically monitoring individuals inside plants. We analysed the stridulatory sounds from 55 bark and ambrosia beetle species within 15 subtribes collected in four countries, making this the largest acoustic dataset of these taxa to date. We characterized and compared the amplitude and spectro-temporal parameters of the distress airborne signals produced by the beetles, in conjunction with phenology and life history data. Sound production was present in $33 \%$ of the collected species, of which $60 \%$ of these sounds had not been previously reported. Depending on species, either both sexes stridulated or only one. Some species had calls with different acoustic morphotypes (one, two, or three notes), and when both sexes stridulated, sounds generally differed. Our data suggest that type of mating system and size play an important role in determining the acoustic communicatory capacity of most species.
\end{abstract}

Keywords: Acoustic communication; bioacoustics; Curculionidae; insect; stridulation; weevil. 


\section{Introduction}

The range of distances over which organisms communicate, in conjunction with the medium they inhabit, dictates what communication mode is possible or most effective (Bossert and Wilson 1963; Naguib and Wiley 2001). Acoustic signals allow for communication in substrates where visual and chemical modes are not reliable (Römer 1998; Hill 2008). For example, organisms that live and breed in chemically-saturated habitats, such as tide pools, or in the dark, such as caves or trees, often rely on sound as a mode of communication (Proakis et al. 2001; Gerhardt and Huber 2002).

Bark beetles and pinhole borers (Coleoptera: Curculionidae, Scolytinae and Platypodinae) are among the many insects that reside and communicate within plant tissue (Vega and Hofstetter 2015), which, unlike water or air, is a medium seldom addressed in communication studies (Hill et al. 2019). These beetles are known as bark and ambrosia beetles, where the term ambrosia refers to a common feeding mode (xylomycetophagy, or mutualistic fungus farming) that evolved independently multiple times within both subfamilies (Kirkendall 1983; Hofstetter et al. 2015). Bark and ambrosia beetles tend to construct tunnels and oviposit within trees (bark beetles typically in phloem; ambrosia beetles in xylem) where adults and larvae feed and complete their development (Vega and Hofstetter 2015). This is a common, but not universal, characteristic of bark and ambrosia beetles, as pith-feeding (myelophagy) and fruit and seed-feeding (spermatophagy) also occur in a variety of taxa (Kirkendall 1983). In some ambrosia beetle species, colonies may persist for several years within the tree, with overlapping generations and life stages within a family unit (i.e., a tunnel system) (Kirkendall 1983). Aggressive tree-killing bark beetles typically have only one generation within a tree, with little or no overlap between life stages (Six and Bracewell 2015), and secondary bark beetles may use the host tree for several generations, depending on moisture and phloem decay rates. Some bark and ambrosia beetles use pheromones to synchronize attacks on trees, or simply to attract mates over long distances, but may use acoustic signals over short distances (particularly within the tree or at the tree surface) (Rudinsky 1969; Rudinsky and Michael 1972; Birch 1984). The beetle that initially colonizes the tree and releases pheromones may be male or female, depending on species (Vega and Hofstetter 2015). In Scolytinae, stridulatory structures are often sexually dimorphic and less-developed or absent in the sex that initiates tunnel construction, regardless of where on the body the stridulatory organ is located (Barr 1969, Hofstetter et al. 2019). This is a common feature in the superfamily 
Curculionoidea where the stridulatory organ often plays an important role in sexual selection (Lyal and King 1996). Nonetheless, stridulatory structures can also be used in other behavioural contexts, including pair formation, rivalry, distress, copulation, pheromone production, and species recognition (Barr 1969; Ryker and Rudinsky 1976; Lyal and King 1996; Bedoya et al. 2019a).

Despite the purported importance of acoustic signals in bark beetles (e.g., Rudinsky 1969; Rudinsky and Michael 1972; Ryker 1984), the signals of only a handful of bark and ambrosia beetle species have been investigated thoroughly. Acoustic signalling appears to be widespread in bark beetles (Barr 1969; Lyal and King 1996), although less so in ambrosia beetles (Ohya and Kinuura 2001; Kirkendall et al. 2015). The Scolytinae and Platypodinae used to be categorized as closely-related subfamilies due to their morphological and behavioural similitudes (Wood and Bright 1982). However, recent phylogenetic studies support a separate origin for both subfamilies (Gillett 2014; Mugu 2018). Acoustic communication is present in at least half of the subtribes of the Scolytinae (Barr 1969; Lyal and King 1996), and it is a common trait among the rest of the CCCMS clade of the Curcolionidae (Conoderinae, Cossoninae, Curculioninae, Molytinae, Scolytinae) (Lyal and King 1996). However, sound production is not ubiquitous and is absent in either one or both sexes in several species. In contrast, sound production is the rule among the Platypodinae and is often found in both sexes (Menier 1976; Ytsma 1988; Lyal and King 1996).

The power of the emitted stridulatory signals of these beetles indicates that these are close range signals and potentially detectable by conspecifics within a few centimetres of the signaller within the tree (Fleming et al. 2013). Although nothing is known about the possible acoustic receptors in bark and ambrosia beetles (Hofstetter et al. 2019), sound production has evolved several times (Barr 1969; Lyal and King 1996). Three primary stridulatory mechanisms within bark beetles (Scolytinae) are known: elytro-tergal, vertex-pronotal, and gula-prosternal stridulatory organs (Barr 1969). In pinhole borers (Platypodinae), only the elytro-abdominal stridulatory mechanism is known to occur (Ytsma 1988; Lyal and King 1996). Bark and ambrosia beetles produce a variety of call types that vary in temporal characteristics and frequency ranges. General call types appear relatively consistent within genera (Rudinsky and Michael 1974; Yturralde 2013), although intraspecific differences occur between chirps produced in different contexts (Michael and Rudinsky 1972; Fleming et al. 2013, Bedoya et al. 2019a ). 
Here, our overarching aim is to appreciably add to the information on bark and ambrosia beetle acoustics to begin to understand the evolution of their acoustic communication. The specific objectives of this study are to (i) characterize the temporal, spectral, and amplitude features of airborne sounds produced by bark and ambrosia beetles across multiple tribes and genera, and (ii) compare the characteristics of the distress/disturbance signals produced across beetle species.

\section{Materials and methods}

\section{Collection of experimental specimens}

A total of 55 bark and ambrosia beetle species were assessed for signal production. Specimens (Table 1) were collected in the United States (Arizona, California, Florida, Georgia, Michigan, Texas), New Zealand (Canterbury, Auckland, Westland), Spain (Canary Islands), and Colombia (Antioquia). This dataset contains phloeophagus (wood-feeding), xylomycetophagus (ambrosia-

feeding), and spermatophagous (seed-feeding) species across 15 subtribes of Scolytinae and Platypodinae, including most of New Zealand's platypodines. All sound-producing species were recorded using the same equipment at two facilities (University of Canterbury, NZ; Northern Arizona University, USA). 
Table 1. List of the collected bark and ambrosia beetle species. Sample (number and sex of tested/recorded individuals, $\sigma^{\top}:$ male,, : female, $\mathbf{n}$ : not identified), Sound (species that stridulated, Y: yes, N: no), Sex (gender with sound production capabilities), Organ (type of stridulatory organ, E-T: elytro-tergal, V-P: vertex-pronotal, G-P: gula-prosternal), Location (where the specimens were collected). See Supplementary Material 2 for the authority of the species named.

\begin{tabular}{|c|c|c|c|c|c|c|}
\hline Tribe: Subtribe & Beetle species & Sample & Sound & Sex & Organ & Location \\
\hline Hylesinini: Hylastina & Hylastes ater & $100^{\pi} 209$ & $\mathrm{Y}$ & $\sigma^{\pi}$ & E-T & Canterbury, NZ \\
\hline Hylesinini: Hylastina & Hylastes porculus & 19 & $\mathrm{~N}$ & & & Georgia, USA \\
\hline Hylesinini: Hylastina & Hylurgops subcostulatus & $10^{7}$ & $\mathrm{Y}$ & $\sigma^{\pi}$ & E-T & Arizona, USA \\
\hline Hylesinini: Hylesinina & Hylesinus aculeatus & $120^{7} 159$ & $\mathrm{Y}$ & $\sigma^{+}$ & E-T & Texas, USA \\
\hline Hylesinini: Hylurgina & Hylurgus ligniperda & $100^{x} 309$ & $\mathrm{Y}$ & $\sigma^{x}$ & E-T & Canterbury, NZ \\
\hline Hylesinini: Phloeosinina & Phloeosinus dentatus & $8 n$ & $\mathrm{~N}$ & & & Texas, USA \\
\hline Hylesinini: Phloeosinina & Phloeosinus cupressi & $120^{7} 129$ & $\mathrm{Y}$ & $\sigma^{\pi}$ & E-T & Canterbury, NZ \\
\hline Hylesinini: Phloeotribina & Phloeotribus liminaris & $2 n$ & $\mathrm{~N}$ & & & Texas, USA \\
\hline Hylesinini: Polygraphina & Carphoborous bicornis & $10^{\top} 29$ & $\mathrm{~N}$ & & & Georgia, USA \\
\hline Hylesinini: Tomicina & Dendroctonus brevicomis & $40^{7} 29$ & $\mathrm{Y}$ & $o^{2} P$ & E-T* & Arizona, USA \\
\hline Hylesinini: Tomicina & Dendroctonus frontalis & $80^{7} 139$ & $\mathrm{Y}$ & $0^{2}+9$ & E-T* & Arizona, USA \\
\hline Hylesinini: Tomicina & Dendroctonus terebrans & $10^{x}$ & $\mathrm{Y}$ & $\sigma^{x}$ & E-T & Georgia, USA \\
\hline Hylesinini: Tomicina & Dendroctonus adjunctus & $40^{7} 69$ & $\mathrm{Y}$ & $\sigma^{+}$ & E-T & Arizona, USA \\
\hline Hylesinini: Tomicina & Dendroctonus pseudotsugae & $70^{7} 89$ & $\mathrm{Y}$ & $\sigma^{\pi}$ & E-T & Arizona, USA \\
\hline Hylesinini: Tomicina & Pachycotes peregrinus & $30 n$ & $\mathrm{~N}$ & & & Westland, NZ \\
\hline Platypodini: Platypodina & Platypus apicalis & $100^{\pi} 29$ & $\mathrm{Y}$ & ơ? & E-T & Westland, NZ \\
\hline Platypodini: Platypodina & Platypus gracilis & $20^{x} 29$ & $\mathrm{Y}$ & $o^{2} P$ & E-T & Westland, NZ \\
\hline Platypodini: Platypodina & Treptoplatypus caviceps & $50^{\pi} 139$ & $\mathrm{Y}$ & $\sigma^{\pi}$ & E-T & Canterbury, NZ \\
\hline Platypodini: Platypodina & Euplatypus parallelus & $20^{7} 19$ & $\mathrm{Y}$ & ơ? & E-T & Florida, USA \\
\hline Scolytini: Corthylina & Gnathotrichus deleoni & $6 n$ & $\mathrm{~N}$ & & & Georgia, USA \\
\hline Scolytini: Corthylina & Gnathotrichus sulcatus & $4 n$ & $\mathrm{~N}$ & & & Georgia, USA \\
\hline Scolytini: Corthylina & Gnathotrichus materiarius & $2 n$ & $\mathrm{~N}$ & & & Florida, USA \\
\hline Scolytini: Corthylina & Monarthrum mali & $3 n$ & $\mathrm{~N}$ & & & Florida, USA \\
\hline Scolytini: Corthylina & Monarthrum fasciatum & $9 n$ & $\mathrm{~N}$ & & & Florida, USA \\
\hline Scolytini: Corthylina & Pityophthorus consimilis & $3 n$ & $\mathrm{~N}$ & & & Florida, Georgia, USA \\
\hline Scolytini: Corthylina & Pityophthorus concentralis & $1 n$ & $\mathrm{~N}$ & & & Florida, USA \\
\hline Scolytini: Corthylina & Pityophthorus confusus & $110^{r} 199 n$ & $\mathrm{~N}$ & & & Georgia, USA \\
\hline Scolytini: Corthylina & Pityophthorus annectens & $20^{x} 1 \mathrm{n}$ & $\mathrm{N}$ & & & Georgia, USA \\
\hline Scolytini: Corthylina & Pityophthorus pulicarius & $10^{x}$ & $\mathrm{~N}$ & & & Georgia, USA \\
\hline Scolytini: Corthylina & Pityophthorus juglandis & $2 n$ & $\mathrm{~N}$ & & & California, USA \\
\hline Scolytini: Corthylina & Pityophthorus liquidambarus & 19 & $\mathrm{~N}$ & & & Georgia, USA \\
\hline Scolytini: Corthylina & $\begin{array}{l}\text { Pseudopityophthorus } \\
\text { minutissimus }\end{array}$ & 19 & $\mathrm{~N}$ & & & Texas, USA \\
\hline Scolytini: Cryphalina & Hypothenemus hampei & $50^{7} 89$ & $\mathrm{~N}$ & & & Antioquia, Colombia \\
\hline Scolytini: Cryphalina & Hypothenemus eruditus & 19 & $\mathrm{~N}$ & & & Georgia, USA \\
\hline Scolytini: Cryphalina & Hypocryphalus sp. ** & $25 n$ & $\mathrm{~N}$ & & & Canterbury, NZ \\
\hline Scolytini: Dryocoetina & Dactylotrypes longicollis & $100^{x} 109$ & $\mathrm{~N}$ & & & Canary Islands, Spain \\
\hline Scolytini: Ipina & Ips pini & 10 ơ 24 우 & $\mathrm{Y}$ & ९ & V-P & Arizona, USA \\
\hline Scolytini: Ipina & Ips avulsus & $240^{\pi} 109$ & $\mathrm{Y}$ & \% & V-P & Georgia, USA \\
\hline Scolytini: Ipina & Ips grandicollis & $300^{7} 199$ & $\mathrm{Y}$ & ९ & V-P & Georgia, USA \\
\hline Scolytini: Ipina & Ips calligraphus & $100^{7} 139$ & $\mathrm{Y}$ & q & V-P & Arizona, USA \\
\hline Scolytini: Ipina & Ips confusus & $8 n$ & $\mathrm{~N}$ & & & Arizona, USA \\
\hline Scolytini: Ipina & Orthotomicus latidens ${ }^{\dagger}$ & $13 n$ & $\mathrm{~N}$ & & & Arizona, USA \\
\hline Scolytini: Ipina & Orthotomicus caelatus & $1 n$ & $\mathrm{~N}$ & & & Florida, USA \\
\hline Scolytini: Scolytina & Scolytus multistriatus & $110^{\pi} 79$ & $\mathrm{~N}$ & & & Auckland, NZ \\
\hline
\end{tabular}




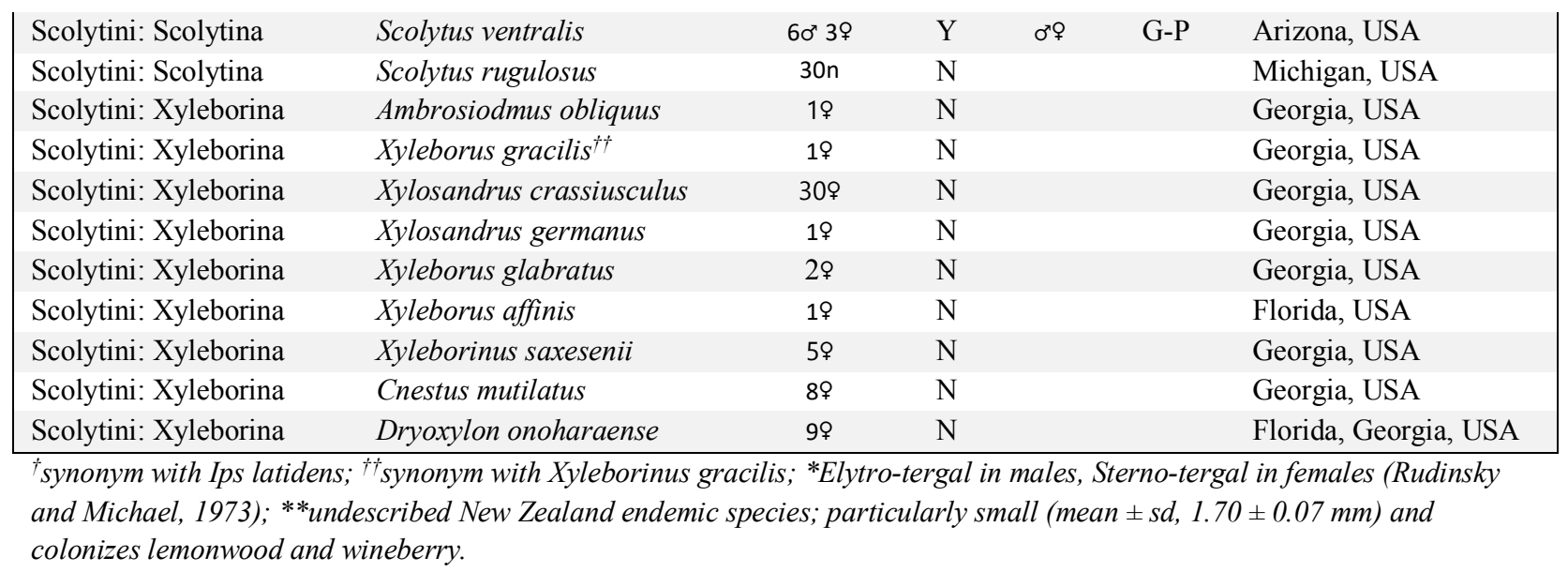

\section{Experimental setup and acoustic data collection}

Sounds were recorded inside a purpose-built soundproof box $(\mathrm{w} \times 1 \times \mathrm{d}, 250 \times 300 \times 100 \mathrm{~mm})$. Individuals were adhered with reusable putty-like adhesive (Blu Tack ${ }^{\mathrm{TM}}$ ) from the antero-dorsal part of the elytra in an upside-down position on top of an acrylic surface. This allowed all the specimens to be recorded at a fixed distance from the microphone without restricting any of the movements needed for sound production, thus standardizing signal acquisition. The elytra are the static part of the compound stridulatory organ in beetles with elytro-tergal stridulation (Lyal and King 1996). In the other two stridulatory mechanisms, i.e., gula-prosternal and vertex-pronotal, it does not play any active role. Distress signals were elicited by physically touching the beetle on the abdomen with a soft paintbrush (Bockingford, 5700R, size 1) and were recorded using an ultrasonic microphone ( $3 \mathrm{~Hz}$ to $50 \mathrm{kHz}$ frequency range and flat frequency response; M50, Earthworks Inc., Milford, NH) positioned $20 \mathrm{~mm}$ from the individual's stridulatory organ. Signals were recorded with a four channel SD 744T audio recorder (Sound Devices LLC, Reedsburg, WI, USA) at a sampling frequency of $96 \mathrm{kHz}, 48 \mathrm{~dB}$ gain, and $24 \mathrm{PCM}$ bit depth.

\section{Analyses}

Recordings were automatically segmented using a threshold based-approach on the mean power distribution in the temporal domain (Bedoya et al. 2019a,b). Every call was then independentlyanalysed in order to extract seven spectro-temporal features. An IIR high pass filter, order 4, at $100 \mathrm{~Hz}$ was used to remove the DC offset. Four spectral (maximum, minimum, centroid, and 
dominant frequencies) and three temporal features (call duration, inter-call interval, and call rate) were selected to describe and compare the recorded species (see Bedoya et al. 2019a for expanded definitions and descriptions). Spectrograms for the computation of the spectro-temporal features were obtained using a flat top-weighted window of size 1024 samples and 768 sample overlap. The size of the FFT was 1024 samples. All reported features were based on the mean values of the spectro-temporal parameters of the individuals within each species (see Table 1 for sample sizes). The discrete-time pressure signal (incident to the microphone) was related to the normalized recording samples by $p_{i}[n]=\left(V_{\text {ref }} / S \cdot G\right) x[n]=1.2114 x[n]$. where $S=36 \cdot 10^{-3}$ is the microphone sensitivity, $G=10^{48 / 20}=251.189(48 \mathrm{~dB})$ is the recorder gain, and $V_{\text {ref }}=10.0545$ is the recorder fullscale voltage. Sound Pressure Level (SPL) spectrums and spectrograms were computed using $L_{p}[n]=20 \log 10\left(p_{i}[n] / p_{0}\right)$, where $L_{p}$ is the SPL signal, and $p_{0}=20 \mu \mathrm{Pa}$ is the reference sound pressure in air. A Principal Component Analysis (PCA) was used to reduce the dimensionality of the data and to compare the acoustic differences among the studied species. Before analysis, all the spectro-temporal features were normalized (0-1) to reduce scale effects. The PCA was estimated using single value decomposition, and the principal components were ordered by the magnitude of their singular values. The automatic call detection, parameter estimation, and PCA were performed in Matlab 2018b. The general description and comparison of the bark beetle sounds was based on the terminology described in Bedoya et al. 2019a.

\section{Results}

Our dataset consisted of species from the three bark and ambrosia beetle tribes: Hylesinini, Scolytini, and Platypodini, and contains recordings of the three main types of stridulatory organs (Figure 1). Most species differed in their use of host material, feeding mode, and mating system. This is the first time the stridulatory structures are imaged for the species exemplified in Figure 1 (i.e., Euplatypus parallelus, Ips avulsus, and Scolytus ventralis). An extended set of images for these three species with magnified sections and detailed measurements is reported in Supplementary Material 1. Correspondingly, Figure 2 contains representative examples of singleand multiple-noted calls of several key species from all tribes and all three stridulatory organs (see Supplementary Material 3 for all recorded species). These sound pressure level (SPL) 
spectrograms depict the variability found within these beetles in all measured spectro-temporal features.

Seven spectro-temporal call parameters $($ mean $\pm \mathrm{sd})$ were estimated for all the recorded species (Table 2). Dendroctonus frontalis, D. brevicomis, Scolytus ventralis, Platypus apicalis, P. gracilis, and Euplatypus parallelus were the only species where both sexes stridulated, whereby the sounds of males and females differed in all cases (Table 2 and Supplementary Material 3). Females of $E$. parallelus had the fastest calling rate, with 7.6 notes per second (nps) on average. In general, pinhole borers (Platypodinae) tended to stridulate louder than the bark beetles (Scolytinae) (Supplementary Material 3). Sounds of $P$. apicalis, were particularly loud and audible to the human ear up to $5 \mathrm{~cm}$ away from the gallery entrance (pers. obs.). 

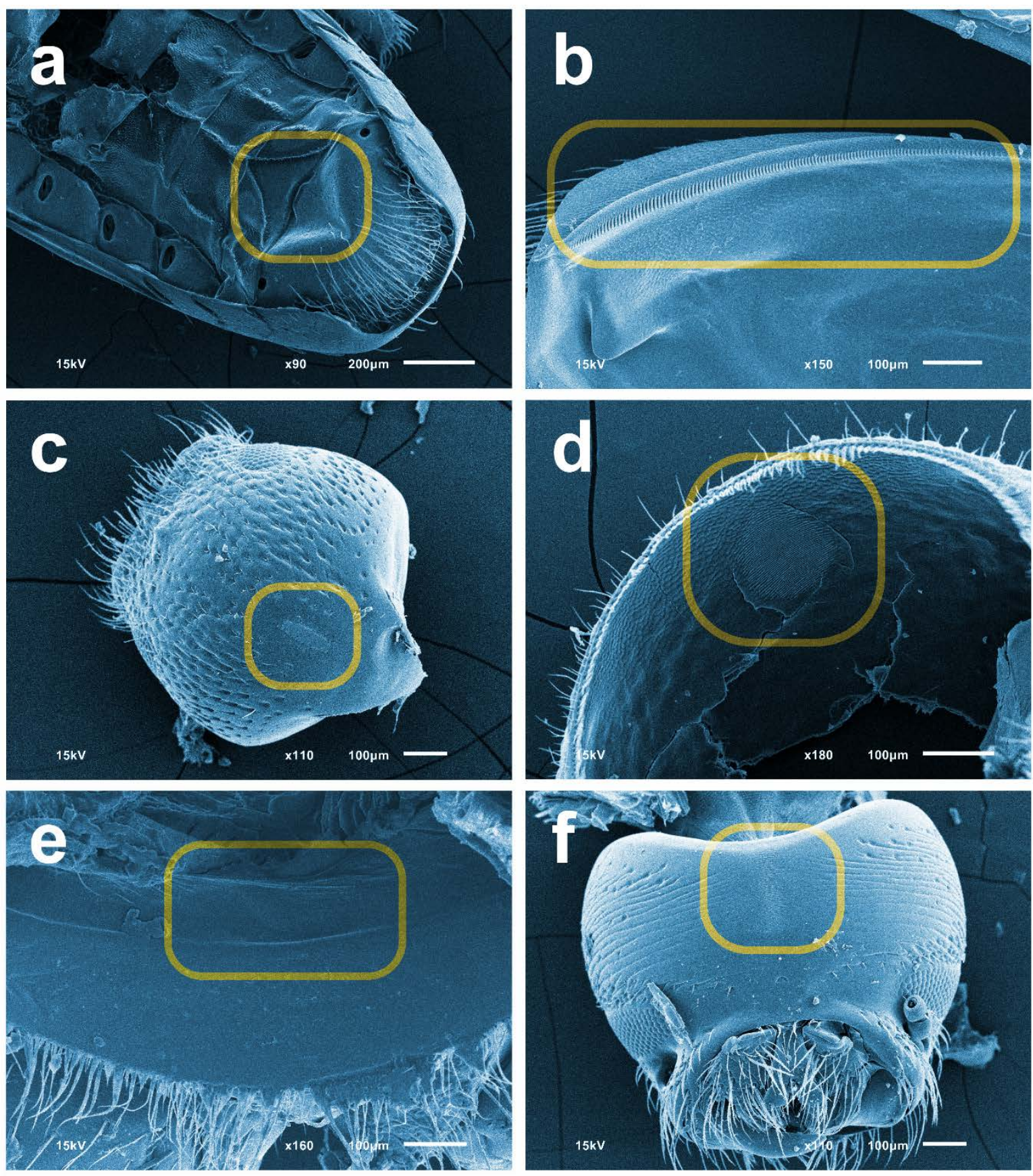

Figure 1. Scanning electron microscope images of the three main types of stridulatory organs (circled in yellow). (a-b) Elytro-tergal (Euplatypus parallelus male), (c-d) Vertex-pronotal (Ips avulsus female), (e-f) gula-prosternal (Scolytus ventralis male). Plectrum (left column - a,c,e) and pars stridens (right column - b,d,f). See Supplementary Material 1 for an extended set of images with close ups and measurement tags. 

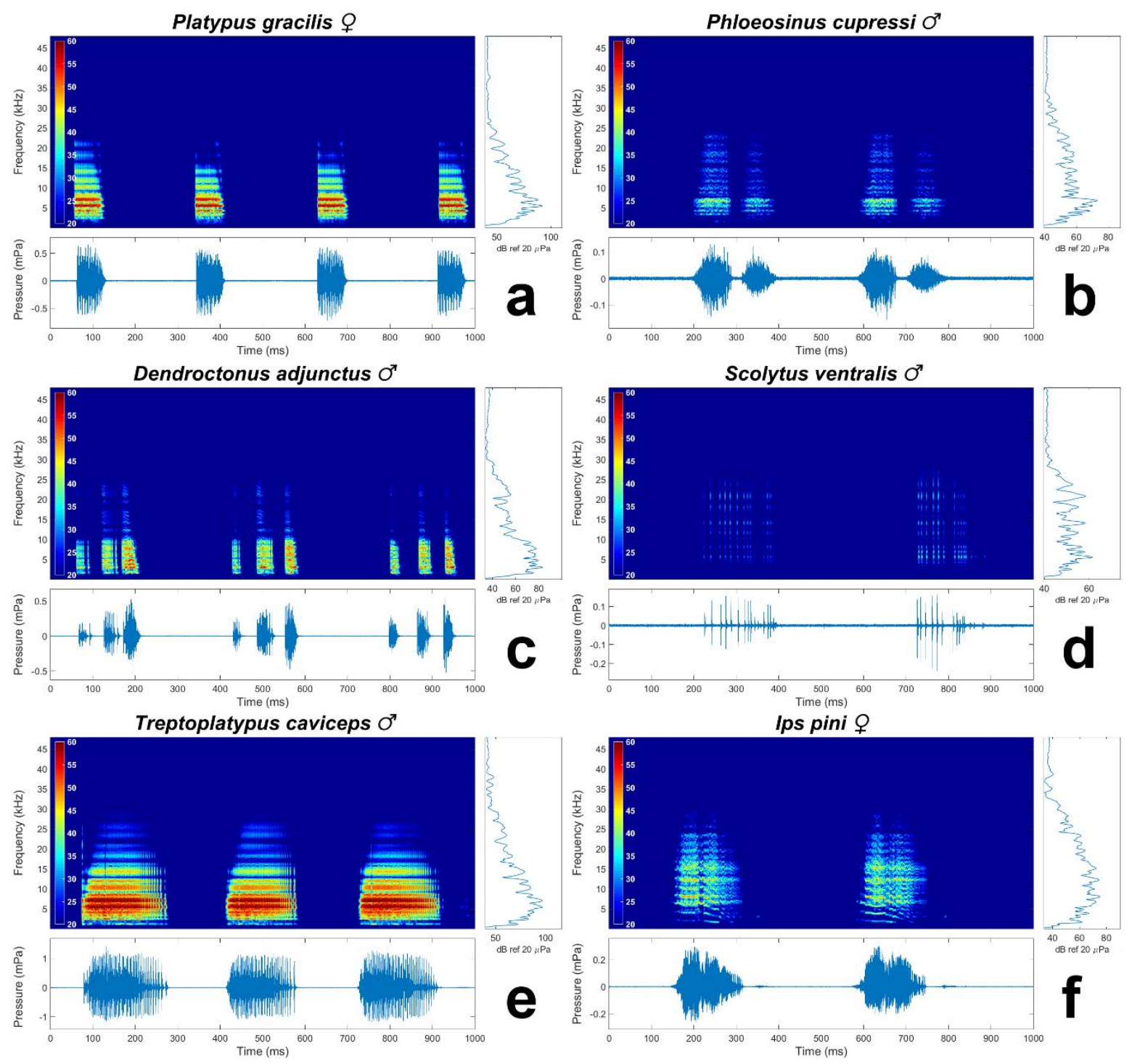

Figure 2. Sound pressure level spectrogram (top), time-domain representation (bottom), and sound pressure level spectrum (right) of representative bark and ambrosia beetle species. Color bars in $\mathrm{dB}(\mathrm{SPL})$ ref $20 \mu \mathrm{Pa}$. The figure depicts species whose calls have a different number of notes $(\mathbf{a}, \mathbf{d}, \mathbf{e}, \mathbf{f}-$ one note, $\mathbf{b}$ - two notes, $\mathbf{c}$ - three notes), different stridulatory organs (a,b,c,e - elytrotergal, $\mathbf{d}$ - gula-prosternal, $\mathbf{f}$ - vertex-pronotal), and represent different tribes (b,c - Hylesinini, d,f - Scolytini, a,e - Platypodini). See Supplementary Material 3 for the complete set of figures. 
Table 2. Spectro-temporal features extracted from the acoustic dataset of beetles (mean $\pm \mathrm{sd})$. Sex (gender with sound production capabilities), Organ (type of stridulatory organ, E-T: elytro-tergal, V-P: vertex-pronotal, G-P: gula-prosternal), Dom (dominant frequency), Cen (spectral centroid), Min (minimum frequency), Max (maximum frequency), ICI (inter-call interval), Dur (call duration), CR (calling rate; notes per second, nps).

\begin{tabular}{|c|c|c|c|c|c|c|c|c|c|}
\hline \multirow[b]{2}{*}{ Species } & \multirow[b]{2}{*}{ Sex } & \multirow[b]{2}{*}{ Organ } & \multicolumn{4}{|c|}{ Spectral (kHz) } & \multicolumn{3}{|c|}{ Temporal } \\
\hline & & & Dom & Cen & Min & Max & ICI (ms) & Dur (ms) & CR (nps) \\
\hline Dendroctonus adjunctus* & $0^{x}$ & E-T & $5.94 \pm 1.94$ & $6.40 \pm 0.58$ & $2.99 \pm 0.13$ & $10.3 \pm 1.68$ & $188.5 \pm 131.4$ & $39.0 \pm 12.2$ & $4.5 \pm 1.6$ \\
\hline Dendroctonus brevicomis & \% & E-T & $7.37 \pm 3.18$ & $8.69 \pm 1.76$ & $3.78 \pm 1.10$ & $16.8 \pm 4.15$ & $416.1 \pm 405.7$ & $36.1 \pm 23.0$ & $2.0 \pm 1.0$ \\
\hline Dendroctonus brevicomis & $0^{x}$ & E-T & $6.03 \pm 1.50$ & $7.41 \pm 1.02$ & $3.86 \pm 0.74$ & $14.3 \pm 4.21$ & $531.7 \pm 312.3$ & $68.1 \pm 27.4$ & $1.5 \pm 0.4$ \\
\hline Dendroctonus frontalis & q & E-T & $7.99 \pm 4.36$ & $10.1 \pm 2.98$ & $3.74 \pm 0.98$ & $21.2 \pm 5.53$ & $226.7 \pm 109.7$ & $27.1 \pm 06.5$ & $3.7 \pm 1.3$ \\
\hline Dendroctonus frontalis & $0^{x}$ & E-T & $7.62 \pm 1.48$ & $9.16 \pm 1.42$ & $3.85 \pm 0.73$ & $18.2 \pm 3.84$ & $184.5 \pm 200.9$ & $59.9 \pm 19.2$ & $4.7 \pm 1.8$ \\
\hline Dendroctonus pseudotsugae & $0^{x}$ & E-T & $4.92 \pm 1.25$ & $5.26 \pm 0.71$ & $2.86 \pm 0.42$ & $8.16 \pm 2.03$ & $268.6 \pm 158.2$ & $36.4 \pm 08.8$ & $3.3 \pm 0.5$ \\
\hline Dendroctonus terebrans & $0^{x}$ & E-T & $22.6 \pm 6.05$ & $22.2 \pm 1.74$ & $6.08 \pm 2.23$ & $39.2 \pm 3.57$ & $557.6 \pm 066.7$ & $99.3 \pm 21.9$ & $2.3 \pm 1.1$ \\
\hline Euplatypus parallelus * & \% & E-T & $9.07 \pm 2.90$ & $13.1 \pm 0.81$ & $4.29 \pm 0.70$ & $27.1 \pm 1.61$ & $044.2 \pm 084.0$ & $42.9 \pm 21.0$ & $7.6 \pm 6.4$ \\
\hline Euplatypus parallelus * & $0^{x}$ & E-T & $4.96 \pm 1.06$ & $6.02 \pm 0.73$ & $3.24 \pm 0.47$ & $10.1 \pm 1.55$ & $194.4 \pm 130.9$ & $37.2 \pm 10.4$ & $5.1 \pm 3.5$ \\
\hline Hylastes ater* & $0^{x}$ & E-T & $7.65 \pm 1.66$ & $8.51 \pm 2.21$ & $3.43 \pm 1.18$ & $13.8 \pm 4.66$ & $501.6 \pm 333.1$ & $98.4 \pm 33.9$ & $1.9 \pm 0.2$ \\
\hline Hylesinus aculeatus & $0^{x}$ & E-T & $7.15 \pm 2.20$ & $9.05 \pm 1.60$ & $4.88 \pm 0.75$ & $19.4 \pm 3.81$ & $118.8 \pm 102.7$ & $29.5 \pm 08.4$ & $7.1 \pm 1.1$ \\
\hline Hylurgops subcostulatus* & $0^{x}$ & E-T & $5.44 \pm 1.24$ & $9.85 \pm 0.73$ & $4.09 \pm 0.29$ & $19.4 \pm 1.34$ & $338.8 \pm 173.8$ & $24.9 \pm 02.7$ & $5.2 \pm 5.8$ \\
\hline Hylurgus ligniperda & $0^{x}$ & E-T & $7.90 \pm 2.29$ & $9.06 \pm 1.98$ & $3.48 \pm 1.26$ & $16.3 \pm 4.92$ & $150.5 \pm 118.0$ & $29.4 \pm 13.6$ & $4.5 \pm 1.3$ \\
\hline Ips avulsus * & \% & V-P & $7.81 \pm 3.40$ & $11.5 \pm 2.50$ & $4.49 \pm 1.38$ & $24.5 \pm 5.03$ & $317.5 \pm 324.0$ & $73.7 \pm 49.4$ & $2.5 \pm 1.2$ \\
\hline Ips calligraphus & q & V-P & $13.3 \pm 10.3$ & $16.8 \pm 6.24$ & $4.53 \pm 2.25$ & $29.5 \pm 8.76$ & $138.8 \pm 228.6$ & $66.2 \pm 53.5$ & $4.9 \pm 1.5$ \\
\hline Ips grandicollis & q & V-P & $8.99 \pm 6.34$ & $12.2 \pm 5.12$ & $4.50 \pm 1.64$ & $23.8 \pm 9.04$ & $164.3 \pm 282.9$ & $59.6 \pm 57.1$ & $4.7 \pm 1.8$ \\
\hline Ips pini & q & V-P & $10.7 \pm 4.74$ & $12.8 \pm 2.79$ & $5.02 \pm 1.88$ & $22.6 \pm 3.49$ & $304.0 \pm 301.7$ & $63.9 \pm 46.5$ & $2.8 \pm 0.6$ \\
\hline Phloeosinus cupressi*广 & $\sigma^{*}$ & E-T & $7.62 \pm 2.67$ & $9.42 \pm 1.44$ & $4.60 \pm 0.71$ & $16.9 \pm 3.26$ & $455.9 \pm 379.0$ & $179.4 \pm 25.9$ & $2.4 \pm 0.7$ \\
\hline Platypus apicalis * & q & E-T & $4.23 \pm 1.46$ & $5.10 \pm 0.90$ & $2.62 \pm 0.35$ & $9.12 \pm 2.38$ & $220.8 \pm 145.9$ & $20.7 \pm 03.6$ & $5.0 \pm 1.1$ \\
\hline Platypus apicalis * & $0^{x}$ & E-T & $6.01 \pm 1.81$ & $6.68 \pm 1.33$ & $3.21 \pm 0.68$ & $11.3 \pm 2.65$ & $232.1 \pm 148.4$ & $40.2 \pm 14.3$ & $4.0 \pm 0.9$ \\
\hline Platypus gracilis * & 운 & E-T & $5.70 \pm 0.49$ & $6.48 \pm 0.40$ & $4.01 \pm 0.41$ & $10.9 \pm 1.51$ & $383.8 \pm 328.7$ & $54.8 \pm 23.5$ & $2.5 \pm 0.9$ \\
\hline Platypus gracilis * & $0^{x}$ & E-T & $8.04 \pm 2.55$ & $8.22 \pm 1.43$ & $4.04 \pm 0.63$ & $13.5 \pm 2.80$ & $359.1 \pm 171.2$ & $75.8 \pm 25.2$ & $2.3 \pm 0.3$ \\
\hline Scolytus ventralis * & q & G-P & $6.03 \pm 1.34$ & $13.6 \pm 3.06$ & $3.43 \pm 0.47$ & $26.2 \pm 8.07$ & $111.5 \pm 120.6$ & $40.2 \pm 21.5$ & $4.9 \pm 0.2$ \\
\hline Scolytus ventralis * & $0^{\pi}$ & G-P & $7.52 \pm 4.17$ & $10.6 \pm 3.14$ & $4.11 \pm 1.05$ & $22.9 \pm 7.50$ & $114.3 \pm 141.2$ & $35.1 \pm 15.3$ & $4.3 \pm 2.2$ \\
\hline Treptoplatypus caviceps* & $0^{\pi}$ & E-T & $5.76 \pm 1.21$ & $7.07 \pm 0.63$ & $3.57 \pm 0.56$ & $13.5 \pm 2.93$ & $414.1 \pm 321.5$ & $131.6 \pm 40.7$ & $1.7 \pm 0.6$ \\
\hline
\end{tabular}

*Species for which calls are reported here for the first time; ${ }^{\dagger}$ P. cupressi has 2-noted calls whose acoustic parameters are reported in this table. For note parameters see Table 3. All other species have single-noted calls.

In general, sounds produced with vertex-pronotal and gula-prosternal organs had less intraorgan acoustic variability, both within and between species, compared with the elytro-tergal case (Table 2), which had highly variable spectral distributions and temporal patterns (Supplementary Material 3). This phenomenon can be observed in the species of the genus Ips, and males and females of $S$. ventralis, where stridulatory sounds are similar among themselves.

In five species, several acoustic morphotypes were identified (Table 3). When the call was composed of a single note, the temporal parameters of the note and call were the same (thus avoiding reporting inter-note intervals and note duration for all species, as these have been stated 
in Table 1; see Bedoya et al. (2019a) for an in-depth description of the notation). Phloeosinus cupressi was the only species whose stridulations were always composed of 2-noted calls; thus, call parameters for this species are reported in Table 2, whereas the note parameters are in Table 3. Dendroctonus adjunctus was the only species with 3-noted calls. After the stimulus was applied, individuals of this species tended to adhere to a single acoustic morphotype for the whole stridulatory process, which lasted several minutes.

Table 3. Temporal features for species with acoustic morphotypes with more than one note. Sex (gender with sound production capabilities), NN (number of notes), INI (inter-note interval), nDur (note duration).

\begin{tabular}{|lcc|cc|}
\hline Species & Sex & NN & INI (ms) & nDur (ms) \\
\hline Dendroctonus adjunctus & $\sigma^{7}$ & 2 & $37.6 \pm 09.6$ & $37.9 \pm 07.3$ \\
Dendroctonus adjunctus & $\sigma^{7}$ & 3 & $30.9 \pm 08.7$ & $35.0 \pm 08.3$ \\
Dendroctonus frontalis & $\sigma^{7}$ & 2 & $18.4 \pm 04.6$ & $37.3 \pm 12.1$ \\
Ips grandicollis & $\wp$ & 2 & $23.3 \pm 09.2$ & $123.8 \pm 59.3$ \\
Phloeosinus cupressi & $\sigma^{7}$ & 2 & $35.0 \pm 25.7$ & $100.5 \pm 25.7$ \\
\hline
\end{tabular}

A PCA was performed to find general acoustic similarities among the studied bark and ambrosia beetle species (Figure 3). The two principal components with the largest eigenvalues explained $86.16 \%$ of the variability of the data: PC1=0.38Dom +0.19 Cen-0.18Min-0.05Max$0.42 \mathrm{ICI}+0.72 \mathrm{Dur}-0.28 \mathrm{CR}$ contributed $46.85 \%$ and $\mathrm{PC} 2=0.40 \mathrm{Dom}-0.34 \mathrm{Cen}-0.11 \mathrm{Min}-0.27 \mathrm{Max}-$ 0.18ICI-0.16Dur+0.75CR the remaining 39.31\%. The four species of the genus Ips, which only possess vertex-pronotal organs, were grouped into one cluster. Both male and female Scolytus ventralis significantly differed from the rest of the species and were part of the same compact cluster, possibly because of the gula-prosternal organ they possess. Most of the species with elytrotergal structures, mainly composed of platypodines and Dendroctonus spp., clustered together. Dendroctonus terebrans was the biggest of the recorded species, and it was one of the species with the longest ICI, duration, and bandwidth (Table 2). Females of E. parallelus had the shortest ICI of all species and the fastest calling rate (Table 2, Supplementary Material 3), followed by $H$. aculeatus (Table 2). Both species were part of the same cluster. The rest of the species with elytrotergal organs were grouped together (Figure 3). 


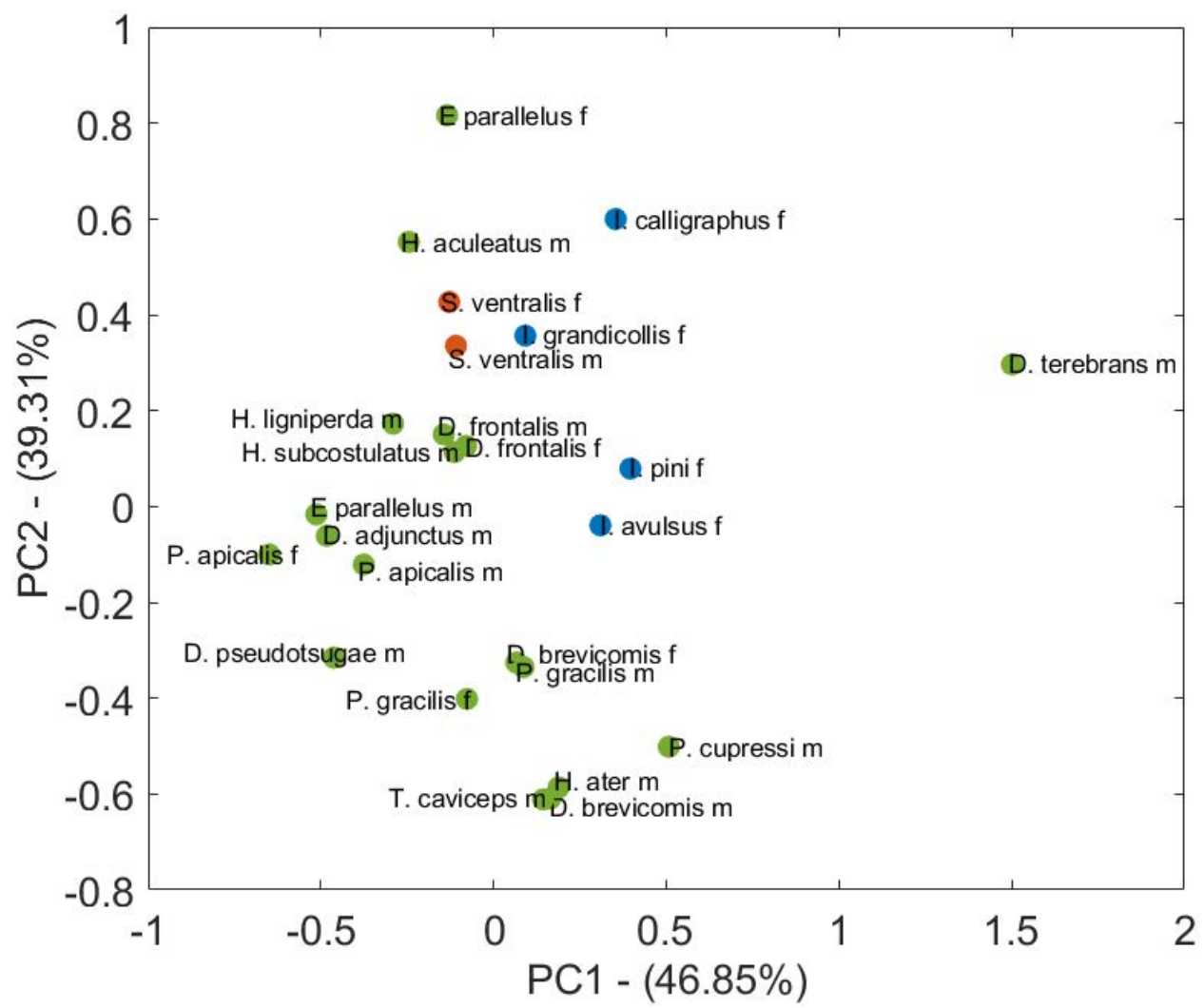

Figure 3. Principal component analysis performed on seven spectro-temporal features (dominant, centroid, minimum and maximum frequencies; call duration, inter-call interval, and call rate) of 19 bark and ambrosia beetle species. Colors represent different stridulatory organs (green: elytrotergal, orange: gula-prosternal, blue: vertex-pronotal). The two principal components explained $86.16 \%$ of the variability of the data. Species with vertex-pronotal and gula-prosternal organs were grouped in compact clusters. With few exceptions, beetles with elytro-tergal organs tended to be together, although are sparsely distributed due to the interspecific variability of the sounds produced by this type of organ.

\section{Discussion}

A total of 55 bark and ambrosia beetle species were collected and their distress calls were examined, but only $33 \%$ of these stridulated. From these 19 stridulating species, seven spectrotemporal features were extracted and used for acoustic comparisons. This is the first report of acoustic signals for 11 of those 19 species, and both sexes stridulated in six of them. To contextualize, this is the largest acoustic dataset collected for the group, yet it does not even contain $1 \%$ of extant bark and ambrosia beetle species. When this information is combined with previous reviews of sound production (Barr 1969; Lyal and King 1996), the number of species investigated 
in this regard is still less than 2\%. Furthermore, there is an evident bias in acoustic studies within the Scolytinae and Platypodinae favouring economically important species with sound production capabilities, and, with few exceptions (e.g., Barr 1969), absence of acoustic communication is not reported in the literature. This information is essential for understanding the acoustic diversity and the evolution of acoustic communication in the group, and we encourage other researchers to report absence of sound production.

In species where both sexes stridulated, calls were acoustically different. This was expected, as sexual dimorphism in the stridulatory apparatus is common in Curculionidae (Barr 1969; Rudinsky 1973; Lyal and King 1996). Regarding intra-specific variation, the existence of several acoustic morphotypes has been reported previously in some bark and ambrosia beetle species (Fleming et al. 2013; Lindeman and Yack 2015). The variation of the number of notes in the call is possible due to the abdominal stretch-and-release mechanism (Lindeman and Yack 2019). In D. adjunctus, note length and note duration become shorter as the number of notes in the call increases, which coincides with the spring-loaded description of the elytro-tergal stridulatory movement reported by Lindeman and Yack (2019).

Our acoustic data collection was limited to the examination of a single behavioural context (i.e., distress/disturbance) due to three experimental and logistical reasons: (i) Bark and ambrosia beetles live inside plant tissue and colonize hosts with different acoustic transmission properties that significantly affect the spectral parameters of the stridulations. This makes acoustic comparisons for all species unworkable in a behavioural context other than distress, as this is the only behaviour where sound production can be reliably controlled and elicited in a common medium (air). (ii) Acoustic data collection of bark and ambrosia beetles is difficult, as most species live and develop inside trees, and specimens must be collected alive, severely curtailing the use of funnel traps, and favouring the felling of trees, manual extraction from the wood, and the use of emergence chambers as the preferred course of action. The latter forms are particularly required for inbreeding polygynous species, where males are flightless and never leave the maternal chamber (Kirkendall 1983), and in economically unimportant species that are difficult to capture in traps because chemical lures are not available. For these reasons, we could only focus on a single behavioral context to maximize the number of species recorded, as testing other behaviours for all specimens would have added significantly to an already labour-intensive task. (iii) During the review of the literature, we found that among all bark and ambrosia beetle species where signals 
have been recorded and reported, distress sounds were always present in at least one of the sexes (Bedoya et al. 2019a,b; Hofstetter et al. 2019; Flemming et al. 2013; Linderman and Yack 2015; Rudinsky and Vallo 1978; Rudinsky 1979; Vernoff and Rudinsky 1980; Yturralde and Hofstetter 2015). Nevertheless, the possibility that some species may have evolved acoustic communication in behavioural contexts other than distress is a limitation of our study. This is especially likely to occur in females, where presence or absence of acoustic communication is disputed in several species (Rudinsky and Michael 1973; Ytsma 1988; Bedoya et al. 2019a).

In behavioural terms, the acoustic responses to physical disturbances are well-known among the Scolytinae and Platypodinae (Rudinsky et al. 1978; Ytsma 1988; Lyal and King 1996; Bedoya et al. 2019a,b). The distress call is hypothesized to work as an agonistic sound to deter predators (Barr 1969; Ryker 1988), but no evidence for this hypothesis has been provided (Fleming et al. 2013). An alternative hypothesis is that it could work as a signal of non-agreement for copulation (e.g., when a male mistakenly mounts another male, as in the beetles of the genus Rhynanchaenus; Claridge 1968; Lyal and King 1996).

Among the recorded Scolytini, Ips avulsus is the smallest Ips species (Wood and Bright 1992), and the smallest beetle (2.5 mm long) with sound production capabilities in our dataset. We were unable to find distress calls in either Scolytus multistriatus or S. rugulosus. On the other hand, in S. ventralis, both sexes stridulated, although less than $30 \%$ of the tested individuals (i.e., 9 beetles) responded to the stimulus. The genus Scolytus has a gula-prosternal stridulatory organ, which differs from the typical elytro-tergal organ found in most bark and ambrosia beetles (Barr 1969; Rudinsky 1979). Particularly, teeth separation in gula-prosternal organs tends to be wider than those of the elytro-tergal and vertex-pronotal organs (Barr 1969), which is a main contributor to the acoustic differences in the sounds the organ produce. Recent molecular phylogenies coincide in a basal separation of the subtribe Scolytina from the rest of the remaining members of the Scolytinae (Pistone et al. 2018), which partly explains the origin of the morphological differences in the stridulatory apparatus.

Among the recorded Hylesinini, Dendroctonus adjunctus was the only species able to produce distress calls consisting of three notes; nonetheless, specimens able to produce one and two notes per call were also found (see Supplementary Material 3 for the acoustic morphotypes). In this genus, females of $D$. brevicomis and $D$. frontalis lack the pars stridens on the ventral surface of the elytra and the plectrum on the seventh abdominal tergite. Instead, the pars stridens appears 
to be located inside the posterior margin of the seventh sternum and the plectrum on the posterior margin of the eight tergite (Rudinsky and Michael 1973). Distress sounds have never been officially reported for any of these species; however, short-distance sounds in female-female interactions had been previously reported in D. brevicomis (Rudinsky and Michael 1973). For females of $D$. frontalis, sound production has never been reported in any behavioral context, although its existence has been suggested due to the presence of a similar stridulatory structure to the one present in D. brevicomis (Rudinsky and Michael 1973). The lack of detection of distress sounds by other researchers can be attributed to the type of stimulus applied, since females of these species do not stridulate when disturbed or "pinched", even under life-threatening situations. However, they stridulate when touched with a soft brush on the ventral surface of the abdomen. Similarly, Rudinsky and Michael (1973) reported sound production by females in female-female interactions in Dendroctonus pseudotsugae, but we were unable to elicit distress sounds from females of this species. Dendroctonus terebrans was the largest of the collected species (with a length of $6.3 \mathrm{~mm}$ on average) and had the largest teeth separation in the pars stridens (Pajares and Lanier 1990), possibly explaining why its sounds did not resemble those of the other Dendroctonus species.

In 1988, Ytsma described the stridulatory apparatuses of most New Zealand platypodines (Brockerhoff et al. 2003) and provided anecdotal observational evidence of sound production for males and females of three species (Platypus apicalis, P. gracilis and Treptoplatypus caviceps), but stridulations were not recorded or reported. Here, we replicated most of Ytsma's findings, although we were unable to find sound production in females of $T$. caviceps, which responded neither to the distress stimulus nor to the sound-eliciting protocol described by Ytsma (1988). Euplatypus parallelus, the only American platypodine accessible to us, had several acoustic similarities with the New Zealand species, having elytro-tergal organs that produced loud and fast single-noted calls in both in males and females.

In contrast to the findings in Platypodinae, none of the ambrosia beetles in Scolytinae stridulated (i.e., Gnathotricus spp., Monarthrum spp., Xyleborus spp., Xylosandrus spp., Xyleborinus saxesenii, Coccotrypes dactyliperda, Ambrosiodmus obliquus, Cnestus mutilatus, and Dryoxylon onoharaense), and for this group we found no recorded signals in the literature. However, stridulatory-like organs which are thought to be sound-producing organs have been described in several xylomycetophagous scolytines (Barr 1969, Paiva and Kiesel 1985). We doubt 
that the feeding mode has any relationship with absence of sound production in these species, as xylomycetophagy is the norm in Platypodinae (Kirkendall 1983), yet they communicate acoustically. We also looked for sound production patterns in species with other feeding modes, but found no distress sounds in the two spermatophagous species examined (H. hampei and $D$. longicollis), although this sample size is too small to draw any reliable conclusions.

We found no stridulatory sounds among the inbreeding polygynous species in our dataset (i.e., Xyleborus spp., Xylosandrus spp., Xyleborinus saxesenii, Hypothenemus spp., Ambrosiodmus obliquus, Cnestus mutilatus, and Dryoxylon onoharaense). None of our xyleborines stridulated, and no species in the Xyleborina subtribe has ever been reported to produce sound. These species mate in the natal nest, where females are usually inseminated by their less numerous brothers (Kirkendall 1983). We hypothesize that in such a mating system, acoustic communication plays a minimal role in mate-finding as the individuals live and reproduce in extremely confined environments and direct contact is almost unavoidable. Aside from this, we also found that none of the small species $(<2.5 \mathrm{~mm})$ in our dataset stridulated, despite having closely-related species with sound production capabilities in the same genus (e.g., P. dentatus). Acoustic communication in insects is hypothesized to be morphologically restricted by size, as muscle power and sound rage tend to be proportional to the mass of the individual (Bennet-Clark 1998). The size of the smallest beetle with sound production in our dataset (I. avulsus, $2.5 \mathrm{~mm}$ ) is similar to the sizes of the smallest insect species with sound production capabilities reported in the literature (i.e., Drosophila melanogaster, $2.7 \mathrm{~mm}$; Micronecta scholtzi, $2.3 \mathrm{~mm}$ ) (Morley et al. 2018; Sueur et al. 2011). Nonetheless, no empirical or theoretical size limits for acoustic communication have been determined. With the exception of a few outliers (e.g. P. peregrinus), mating system and size are enough to predict the presence or absence of acoustic communication in most of the recorded bark and ambrosia beetle species in this study. Nonetheless, this hypothesis, and the interaction between mating system and size, is something that needs to be tested with a larger dataset.

Species of the genus Ips were the only harem polygynous species in our dataset with sound production capabilities. These have a less common type of stridulatory organ (vertex-pronotal) than most bark and ambrosia beetles and only females stridulate (Barr 1969), suggesting a different evolutionary origin for acoustic communication in this taxon. This contrasts with previous reports of the polygynous genus Polygraphus where both sexes are able to acoustically communicate with elytro-tergal organs (Barr 1969, Lyal and King 1996). With the exception of the genera Ips and 
Scolytus, whose lineage was described above, the rest of the recorded species were monogamous and possessed elytro-tergal organs.

The most prominent result of the PCA (see also Supplementary Material 3) was the high diversity in sounds produced with elytro-tergal organs, which did not cluster together as they did with vertex-pronotal and gula-prosternal organs. This can be mainly attributed to the fact that "elytro-tergal" is an umbrella term for a set of different stridulatory organs (Lyal and King 1996). In spite of being the most common type of sound-producing organ in weevils, the morphology and location of both the plectrum and pars stridens vary significantly across taxa (Lyal and King 1996). For instance, in the Platypodinae, the plectrum is located on the anterior part of the seventh abdominal tergite and the pars stridens is along the left elytral sutural flange (Lyal and King 1996; Ytsma 1988). Furthermore, the plectrum is sexually dimorphic and possesses inter-specific variability (Menier 1976, Ytsma 1988). In the Scolytinae, the plectrum is located on the posterior margin of the seventh abdominal tergite and the pars stridens is on the ventral surface of the elytron (Barr 1969; Lyal and King 1996; Bedoya et al. 2019a). The plectrum differs from that of the Platypodinae and, in most species, consists of a pair of tuberculiform processes (Lyal and King 1996). Aside from this, some genera, such as Dendroctonus, have inter-sexual differences in the stridulatory apparatus, where both plectrum and pars stridens are located in different parts of the body (Rudinsky and Michael 1973). Another factor expected to contribute to interspecific variability in bark and ambrosia beetle stridulations is morphology. Despite having a simplistic sound production mechanism (Lindeman and Yack 2019), species that share the same type of elytro-tergal organ will produce distinctive sounds due to differences in the spacing of teeth in the pars stridens, size of the plectrum, shape of the elytra, and speed of the ventral movement. These morphological differences contribute to small interspecific differences in the estimated acoustic features that become more evident when all features are combined and analysed in multidimensional space.

Recent phylogenies refuting a close relationship between the Scolytinae and Platypodinae (Mugu et al. 2018), differences between the elytro-tergal organs of these subfamilies, and the absence of acoustic communication in closely-related groups to the Platypodinae (i.e., Dryophthorinae) suggest that acoustic communication has an independent evolutionary origin in these two subfamilies, and that this is a case of convergent evolution. Additionally, our data suggest that the type of mating system and beetle size play an important role in determining the 
acoustic communicatory capacity of most species. However, additional information is needed in order to make a strong case for the hypothesis that there are co-evolutionary patterns in mating systems, stridulatory-organs, and acoustic communication in bark beetles.

\section{Acknowledgements}

We sincerely thank all the researchers and collaborators who helped in obtaining and identifying specimens including Thomas Atkinson, Paul Bradbury, Jon Dronfield, Allani Gonzalez, Emily Haworth, Jiri Hulcr, Anders Isaksen, Andrew Johnson, Lawrence Kirkendall, Emelia Lawrence, Stephen Pawson, Anouchka Perret-Gentil, Marcos Riquelme, Rodrigo Sanchez, Sara Smith, Carl Wardhaugh, and John Wardle. We also thank A.N. Bobylev (Tyumen State University, Siberia Russia) for preparing the SEM images.

\section{Disclosure statement}

No potential conflict of interest was reported by the authors.

\section{Funding}

This study was funded by the New Zealand Ministry of Business, Innovation, and Employment (MBIE), grant C04X1407, the Better Border Biosecurity Collaboration (b3nz.org) via MBIE Core Funding to Scion, and Catalyst: Seeding funding from the Royal Society of New Zealand (grant CSG-FRI1701). 


\section{References}

Barr BA. 1969. Sound production in Scolytidae (Coleoptera) with emphasis on the genus Ips. Can Entomol. 101(6):636-672.

Bedoya CL, Brockerhoff EG, Hayes M, Pawson SM, Najar-Rodriguez A, Nelson XJ. 2019a. Acoustic communication of the red-haired bark beetle (Hylurgus ligniperda). Physiol Entomol. (In press).

Bedoya CL, Nelson XJ, Hayes M, Hofstetter RW, Atkinson TH, Brockerhoff EG. 2019b. First report of luminous stimuli eliciting sound production in weevils. Sci Nat. 106(17):1-4.

Bennet-Clark HC. 1998. Size and scale effects as constraints in insect sound communication. Phil. Trans. R. Soc. Lond. B. 353(1367):407-419.

Birch MC. 1984. Aggregation in Bark Beetles. In: Bell WJ and Cardé RT, editors. Chemical Ecology of Insects. Boston (MA): Springer. pp. 331-353.

Bossert WH, Wilson EO. 1963. The analysis of olfactory communication among animals. J Theor Biol. 5(3):443-469.

Brockerhoff EG, Knížek M, Bain J. 2003. Checklist of indigenous and adventive bark and ambrosia beetles (Curculionidae: Scolytinae and Platypodinae) of New Zealand and interceptions of exotic species (1952-2000). NZ Entomol. 26(1):29-44.

Claridge LC. 1968. Sound production in species of Rhynchaenus ( = Orchestes) (Coleoptera: Curculionidae), T Roy Entomol Soc London. 120:287-296.

Čokl A, Virant-Doberlet M. 2003. Communication with substrate-borne signals in small plantdwelling insects. Annu Rev Entomol. 48(1):29-50.

Fleming AJ, Lindeman AA, Carroll AL, Yack JE. 2013. Acoustics of the mountain pine beetle (Dendroctonus ponderosae) (Curculionidae, Scolytinae): sonic, ultrasonic, and vibration characteristics. Can J Zool. 91(4):235-244.

Gerhardt HC, Huber F. 2002. Acoustic communication in insects and anurans: common problems and diverse solutions. Chicago (IL): University of Chicago Press.

Gillett CP, Crampton-Platt A, Timmermans MJ, Jordal BH, Emerson BC, Vogler AP. 2014. Bulk de novo mitogenome assembly from pooled total DNA elucidates the phylogeny of weevils (Coleoptera: Curculionoidea). Mol Biol Evol. 31(8): 2223-2237.

Hill PS. 2008. Vibrational communication in animals. Boston (MA): Harvard University Press.

Hill PS, Lakes-Harlan R, Mazzoni V, Narins P, Virant-Doberlet M, Wessels A. 2019. Biotremology: Studying Vibrational Behavior. Animal Signals and Communication book series. Berlin Heidelberg: Springer.

Hofstetter RW, Dinkins-Bookwalter J, Klepzig KD, Davis TS. 2015. Symbiotic associates of bark beetles. In: Vega F and Hofstetter RW, editors. Bark beetles: Biology and Ecology of Native and Invasive Species. San Diego (CA): Academic Press. pp. 209-246.

Hofstetter RW, Aflitto N, Bedoya CL, Yturralde K, Dunn DD. 2019. Chapter 20: Vibrational behavior in bark beetles - applied aspects. In: Hill PSM, et al., editors. Biotremology studying vibrational behavior. Animal signals and communication series. Springer.

Kirkendall LR. 1983. The evolution of mating systems in bark and ambrosia beetles (Coleoptera: Scolytidae and Platypodidae). Zool J Linn Soc. 77(4):293-352.

Kirkendall LR, Biedermann PH, Jordal BH. 2015. Evolution and diversity of bark and ambrosia beetles. In: Vega F and Hofstetter RW, editors. Bark beetles: Biology and Ecology of Native and Invasive Species. San Diego (CA): Academic Press. pp. 85-156. 
Lindeman AA, Yack JE. 2015. What is the password? Female bark beetles (Scolytinae) grant males access to their galleries based on courtship song. Behav Process. 11:123-131.

Lindeman AA, Yack JE. 2019. Bark beetles use a spring-loaded mechanism to produce variable song patterns. J Exp Biol. jeb.190660.

Lyal CHC, King T. 1996. Elytro-tergal stridulation in weevils (Insecta: Coleoptera: Curculionoidea). J Nat Hist. 30(5):703-773.

Menier JJ. 1976. Existence d'appareils stridulatoires chez les Platypodidae (Coleoptera), Ann Soc Entomol FR. 12:347-353.

Morley EL, Jonsonn T, Robert D. 2018. Auditory sensitivity, spatial dynamics, and amplitude of courtship song in Drosophila melanogaster. J Acoust Soc Am 144(2):734-739.

Mugu S, Pistone D, Jordal BH. 2018. New molecular markers resolve the phylogenetic position of the enigmatic wood-boring weevils Platypodinae (Coleoptera: Curculionidae). Arthropod Systematics and Phylogeny. 76:45-58.

Naguib M, Wiley RH. 2001. Estimating the distance to a source of sound: mechanisms and adaptations for long-range communication. Anim Behav. 62(5):825-837.

Ohya E, Kinuura H. 2001. Close range sound communications of the oak platypodid beetle Platypus quercivorus (Murayama) (Coleoptera: Platypodidae). Appl Entomol Zool. 36(3):317-321.

Paiva MR, Kiesel K. 1985. Lineatin biosynthesis and interspecific communication in Trypodendron spp. (Col., Scolytidae). Mitt dtsch Ges allg angew Ent. 4:402-405.

Pajares JA, Lanier GN. 1990. Biosystematics of the turpentine beetles Dendroctonus terebrans and D. valens (Coleoptera: Scolytidae), Ann Entomol Soc Am. 83(2):171-188.

Pistone D, Gohli J, Jordal BH. 2018. Molecular phylogeny of bark and ambrosia beetles (Curculionidae: Scolytinae) based on 18 molecular markers. Syst Entomol. 43:387-406.

Proakis JG, Sozer EM, Rice JA, Stojanovic M. 2001. Shallow water acoustic networks. IEEE Comm Mag. 39(11):114-119.

Römer H. 1998. The sensory ecology of acoustic communication in insects. In: Hoy RR, Popper AN, Fay RR, editors. Comparative hearing: insects. New York (NY): Springer. pp. 63-96.

Rudinsky JA. 1969. Masking of the aggregation pheromone in Dendroctonus pseudotsugae Hopk. Science 166(3907):884-885.

Rudinsky JA. 1979. Chemoacoustically induced behavior of Ips typographus (Col.: Scolytidae). Z Ang Ent. 88:537-541.

Rudinsky JA, Michael RR. 1972. Sound production in Scolytidae: Chemostimulus of sonic signal by the Douglas-fir beetle. Science 175(4028):1386-1390.

Rudinsky JA, Michael RR. 1973. Sound production in Scolytidae: Stridulation by female Dendroctonus beetles. J Insect Physiol. 19(3):689-705.

Rudinsky JA, Michael RR. 1974. Sound production in Scolytidae: 'Rivalry' behaviour of male Dendroctonus beetles. J Insect Physiol. 20(7):1219-1230.

Rudinsky JA, Vallo V. 1978. The ash bark beetles Leperisinus fraxini and Hylesinus oleiperda: stridulatory organs, acoustic signals, and pheromone production. Z Angew Entomol. 87:417429.

Rudinsky JA, Vallo V, Ryker LC. 1978, Sound production in Scolytidae: Attraction and stridulation of Scolytus mali (Col., Scolytidae). J Appl Entomol. 86: 381-391.

Ryker LC. 1984. Acoustic and chemical signals in the life cycle of a beetle. Sci Am. 250(6):112123.

Ryker LC. 1988. Acoustic studies of Dendroctonus bark beetles. Fla Entomol. 71(4):447-461. 
Ryker LC, Rudinsky JA. 1976. Sound production in Scolytidae - acoustic signals of male and female Dendroctonus valens Leconte. J Appl Entomol. 80(2):113-118.

Six DL, Bracewell R. 2015. Dendroctonus. In: Vega F and Hofstetter RW, editors. Bark beetles: biology and ecology of native and invasive species. San Diego (CA): Academic Press. pp. $305-350$.

Sueur J, Mackie D, Windmill JFC. 2011. So small, so loud: Extremely high sound pressure level from a pygmy aquatic insect (Corixidae, Micronectinae). PLoS ONE 6(6): e21089.

Vega FE, Hofstetter RW. (eds) 2015. Bark beetles: biology and ecology of native and invasive species. San Diego (CA): Academic Press.

Vernoff S, Rudinsky JA. 1980. Sound production and pairing behavior of Leperisinus californicus Swaine and L. oregonus Blackman (Coleoptera: Scolytidae) attacking Oregon ash. Z Angew Entomol. 90:58-74.

Wood SL, Bright DE. 1992. A catalog of Scolytidae and Platypodidae (Coleoptera), Part 2. Taxonomic index volume A. Great Basin Nat. 13:1-1533.

Ytsma G. 1988. Stridulation in Platypus apicalis, P. caviceps, and P. gracilis (Col., Platypodidae). J Appl Entomol. 105(1-5):256-261.

Yturralde KM. 2013. The acoustic ecology of bark beetles and bed bugs. PhD thesis, Northern Arizona University, School of Forestry, Flagstaff AZ.

Yturralde KM, Hofstetter RW. 2015. Characterization of stridulatory structures and sounds of the larger mexican pine beetle, Dendroctonus approximatus (Coleoptera: Curculionidae: Scolytinae). Fla Entomol. 98(2):516-527. 
Supplementary Material 1 - List of species with author's names

\begin{tabular}{|c|c|}
\hline \multicolumn{2}{|c|}{ Beetle species } \\
\hline Ambrosiodmus obliquus (LeConte) & Monarthrum mali (Fitch) \\
\hline Carphoborus bicornis Wood & Orthotomicus caelatus (Eichhoff) \\
\hline Cnestus mutilatus (Blandford) & Orthotomicus latidens (LeConte) \\
\hline Dactylotrypes longicollis (Wollaston) & Pachycotes peregrinus (Chapuis) \\
\hline Dendroctonus adjunctus Blandford & Phloeosinus cupressi Hopkins \\
\hline Dendroctonus brevicomis LeConte & Phloeosinus dentatus (Say) \\
\hline Dendroctonus frontalis Zimmermann & Phloeotribus liminaris (Harris) \\
\hline Dendroctonus pseudotsugae Hopkins & Pityophthorus annectens (LeConte) \\
\hline Dendroctonus terebrans (Olivier) & Pityophthorus concentralis Eichhoff \\
\hline Dryoxylon onoharaense (Murayama) & Pityophthorus confusus Blandford \\
\hline Euplatypus parallelus (F.) & Pityophthorus consimilis LeConte \\
\hline Gnathotrichus deleoni Blackman & Pityophthorus juglandis Blackman \\
\hline Gnathotrichus materiarius (Fitch) & Pityophthorus liquidambarus Blackman \\
\hline Gnathotrichus sulcatus (LeConte) & Pityophthorus pulicarius (Zimmermann) \\
\hline Hylastes ater Paykull & Platypus apicalis White \\
\hline Hylastes porculus Erichson & Platypus gracilis Broun \\
\hline Hylesinus aculeatus Say & $\begin{array}{l}\text { Pseudopityophthorus minutissimus } \\
\text { (Zimmermann) }\end{array}$ \\
\hline Hylurgops subcostulatus (Mannerheim) & Scolytus multistriatus (Marsham) \\
\hline Hylurgus ligniperda (F.) & Scolytus rugulosus (Muller) \\
\hline Hypocryphalus sp. ${ }^{*}$ & Scolytus ventralis LeConte \\
\hline Hypothenemus eruditus Westwood & Treptoplatypus caviceps Broun \\
\hline Hypothenemus hampei (Ferrari) & Xyleborinus saxesenii (Ratzeburg) \\
\hline Ips avulsus (Eichhoff) & Xyleborus affinis Eichhoff \\
\hline Ips calligraphus (Germar) & Xyleborus glabratus Eichhoff \\
\hline Ips confusus (LeConte) & Xyleborus gracilis \\
\hline Ips grandicollis (Eichhoff) & Xylosandrus crassiusculus (Motschulsky) \\
\hline Ips pini (Say) & Xylosandrus germanus (Blandford) \\
\hline Monarthrum fasciatum (Say) & \\
\hline
\end{tabular}

*undescribed species 
Supplementary Material 2 - Additional scanning electron microscope (SEM) images of the stridulatory organs
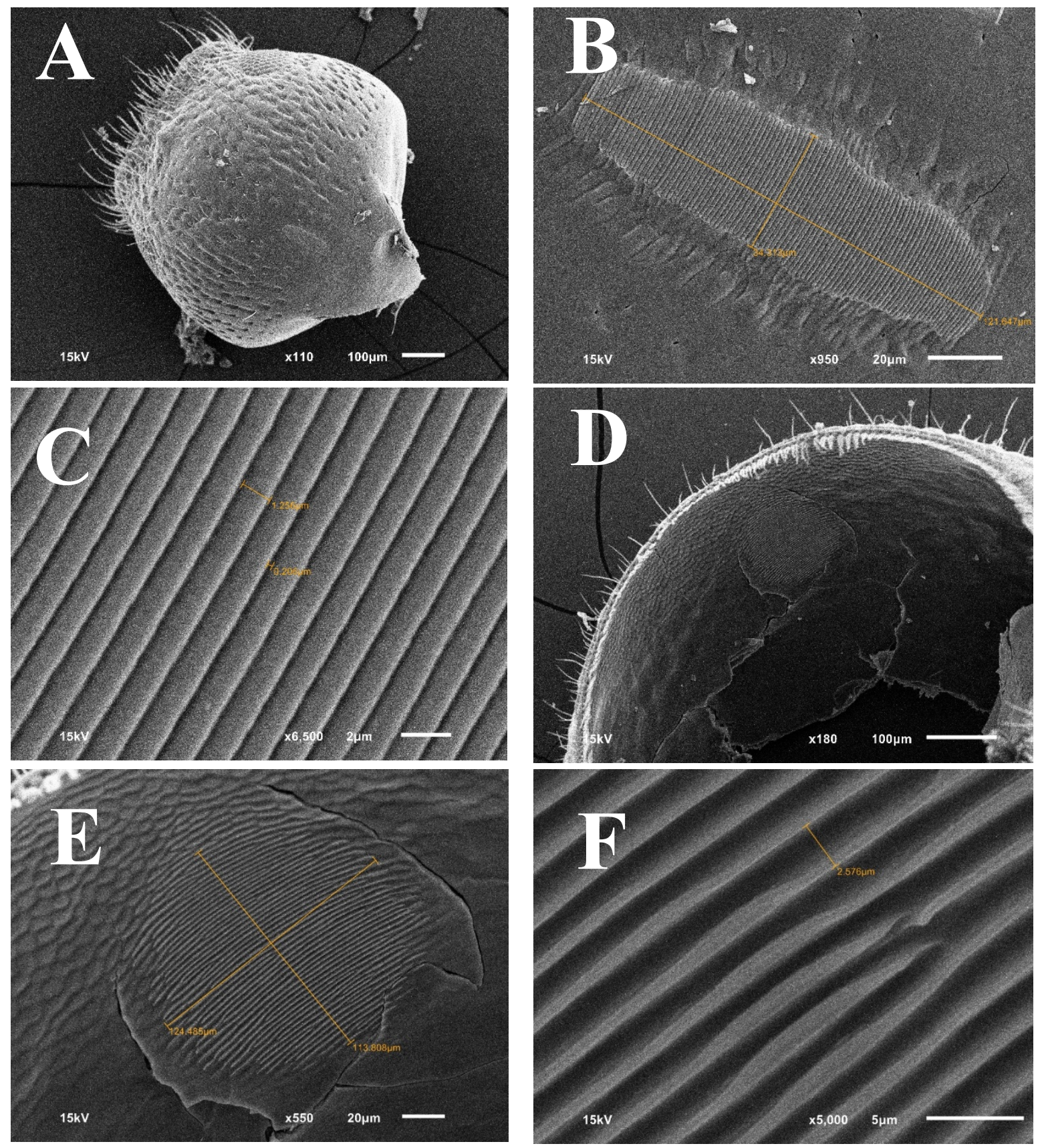

Figure 1-A2. A Ips avulsus female head with vertex exposed. Stridulatory structures (pars stridens) are located on posterior end of the head (B), seen in the central-lower right, usually hidden by the pronotum. B Detail of I. avulsus pars stridens presented in A. This part of the compound stridulatory organ consists of an elliptically-shaped file of teeth located on the posterior part of the vertex. C Detail of the file of teeth of the I. avulsus female pars stridens presented in B. D Ips avulsus female plectrum located on the ventral surface of the pronotum. E Detail of the I. avulsus 
female plectrum presented in $\mathbf{D}$. It consists of a circular file of teeth similar to the pars stridens. It is shorter and wider than the pars stridens and has wider distances between the teeth. $\mathbf{F}$ Magnification of I. avulsus female plectrum presented in E.
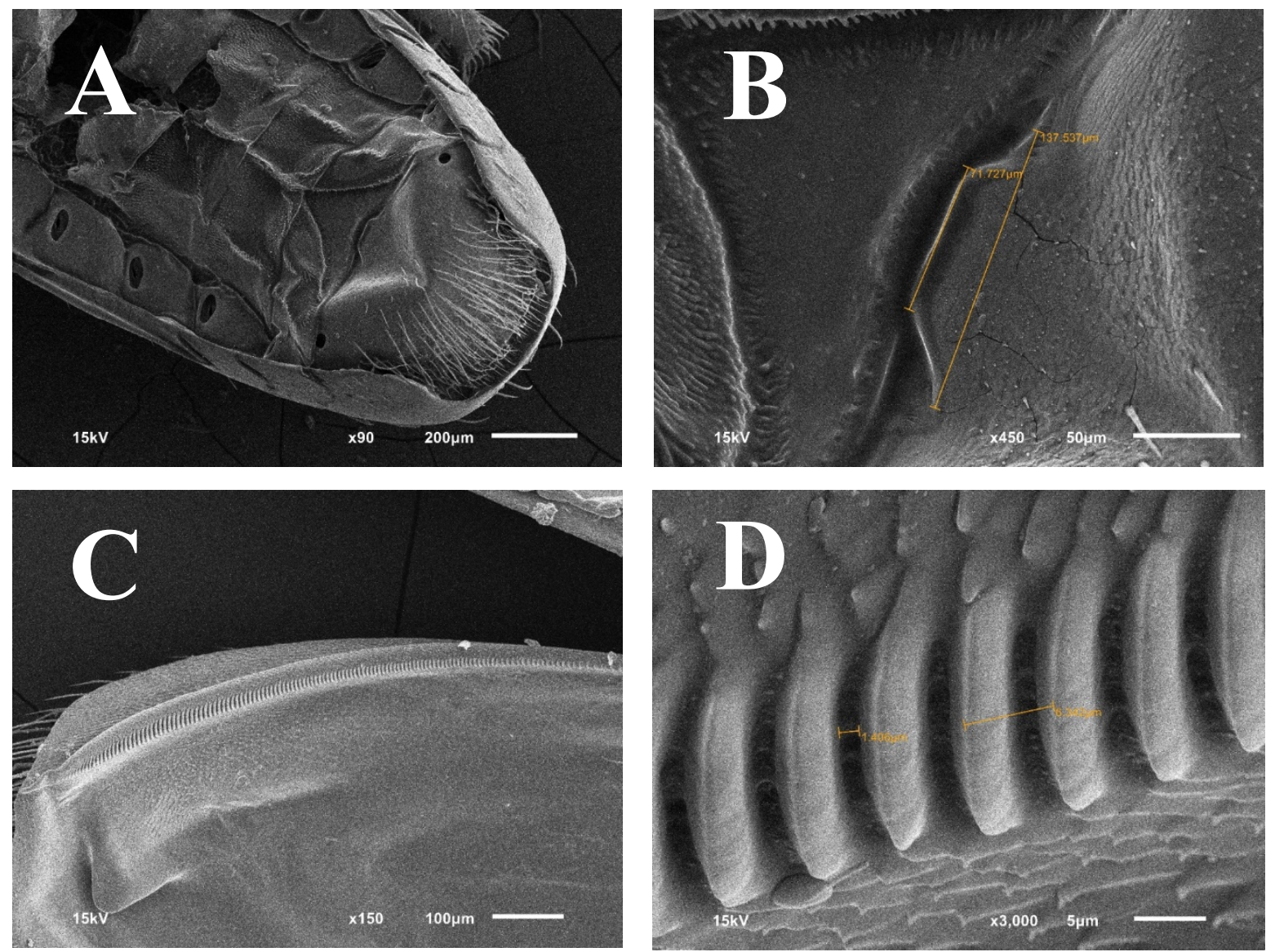

Figure 3-A2. A Dorsal view of a male individual of Euplatypus parallelus with the elytra removed. The plectrum (B) is located at the anterior end of the last abdominal tergite. B Detail of the $E$. parallelus plectrum presented in A. C Ventral view of the left elytron of a male individual of Euplatypus parallelus. The pars stridens is visible on the edge of the structure. D Magnification of the file of teeth that compose the pars stridens presented in C.
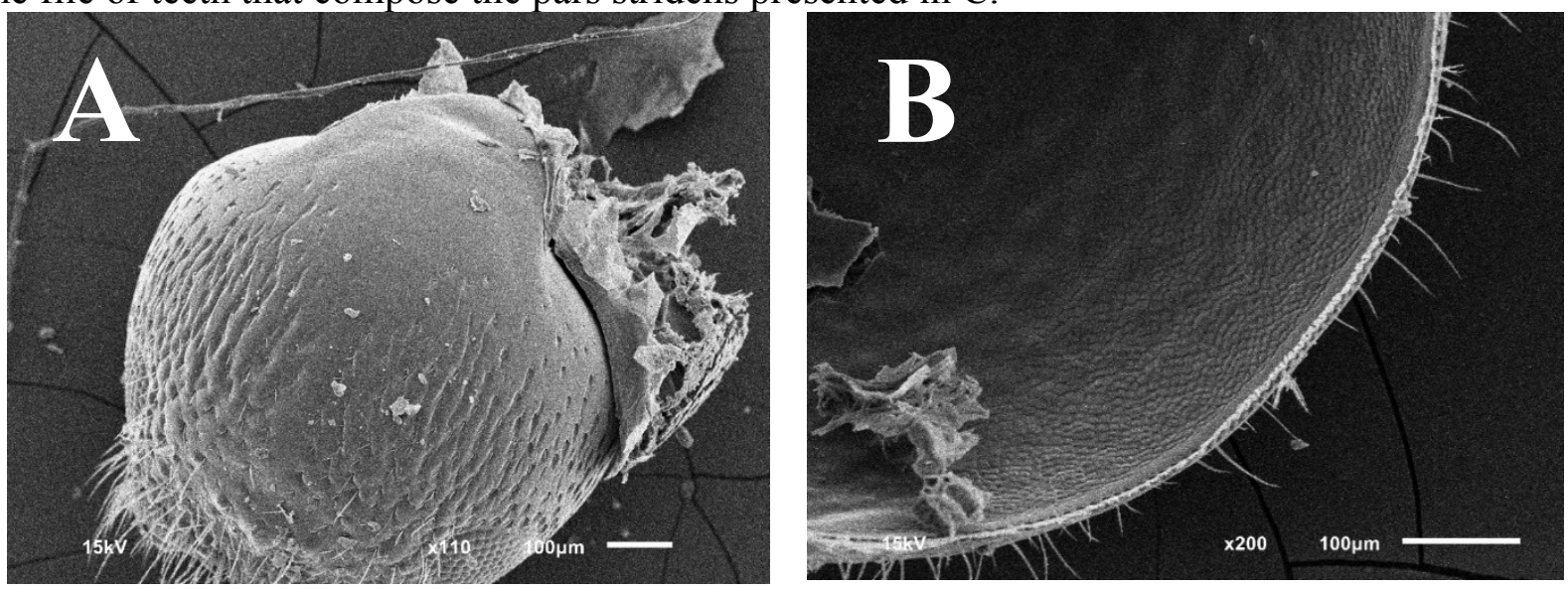
Figure 2-A2. A Ips avulsus male head. Note the absence of stridulatory structures. B Ventral view of the pronotum of a male individual of Ips avulsus. Note the absence of stridulatory structures.
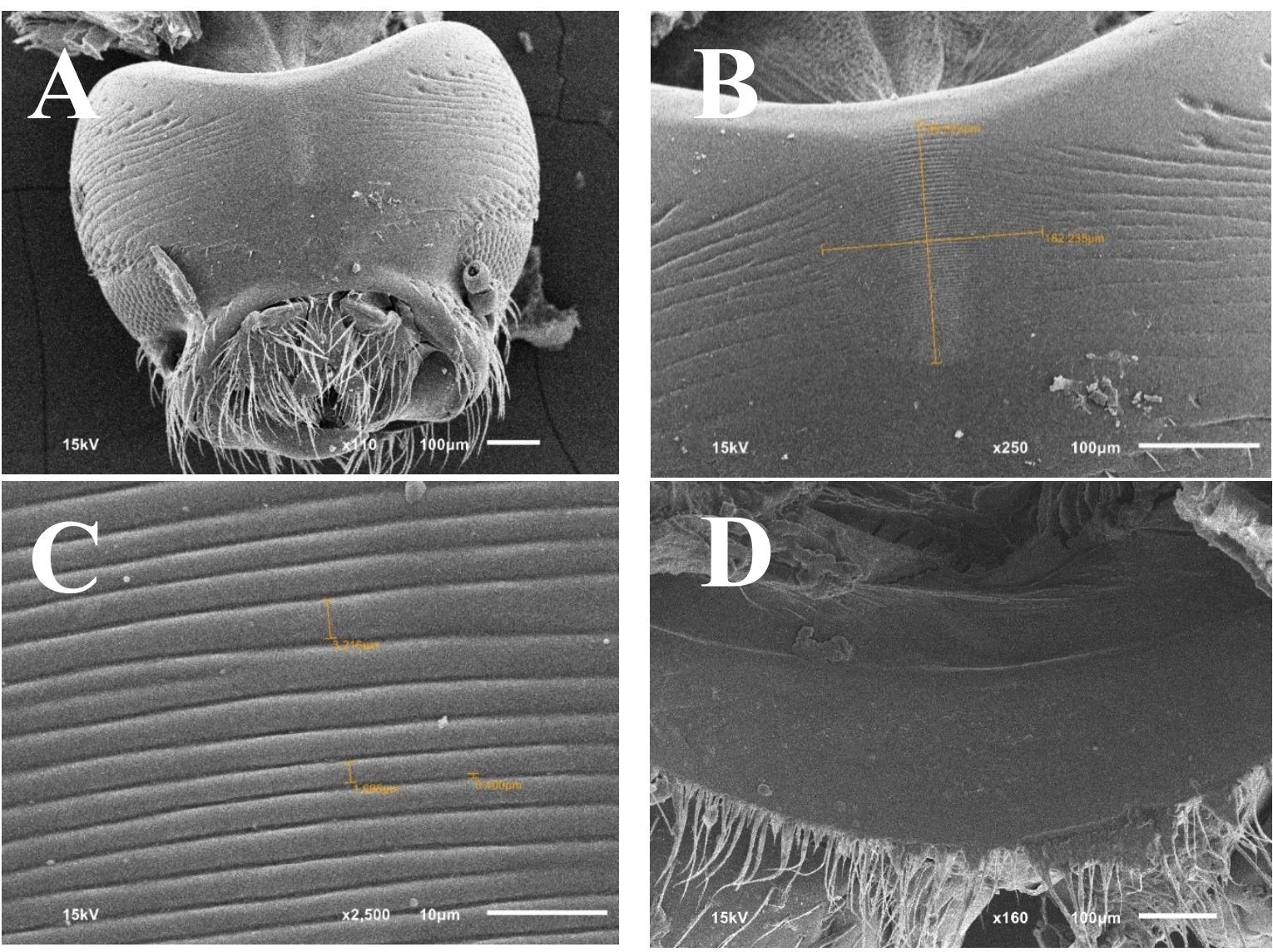

Figure 4-A2. A Ventral view of the head of a male individual of Scolytus ventralis. The pars stridens consists of a circularly-shaped set of ridges embedded on the gula. B Close-up of the pars stridens described in A. C Detail of the ridges of the $S$. ventralis pars stridens from B. D Plectrum of $S$. ventralis. The structure consists of a pair of ridges on the ventral surface of the thorax. 
Supplementary Material 3 - Sound pressure level spectrograms of all the recorded bark and ambrosia beetle species. Sound pressure level spectrogram (top), time-domain representation (bottom), and sound pressure level spectrum (right). Colourbars in $d B(S P L)$ ref $20 \mu P a$.
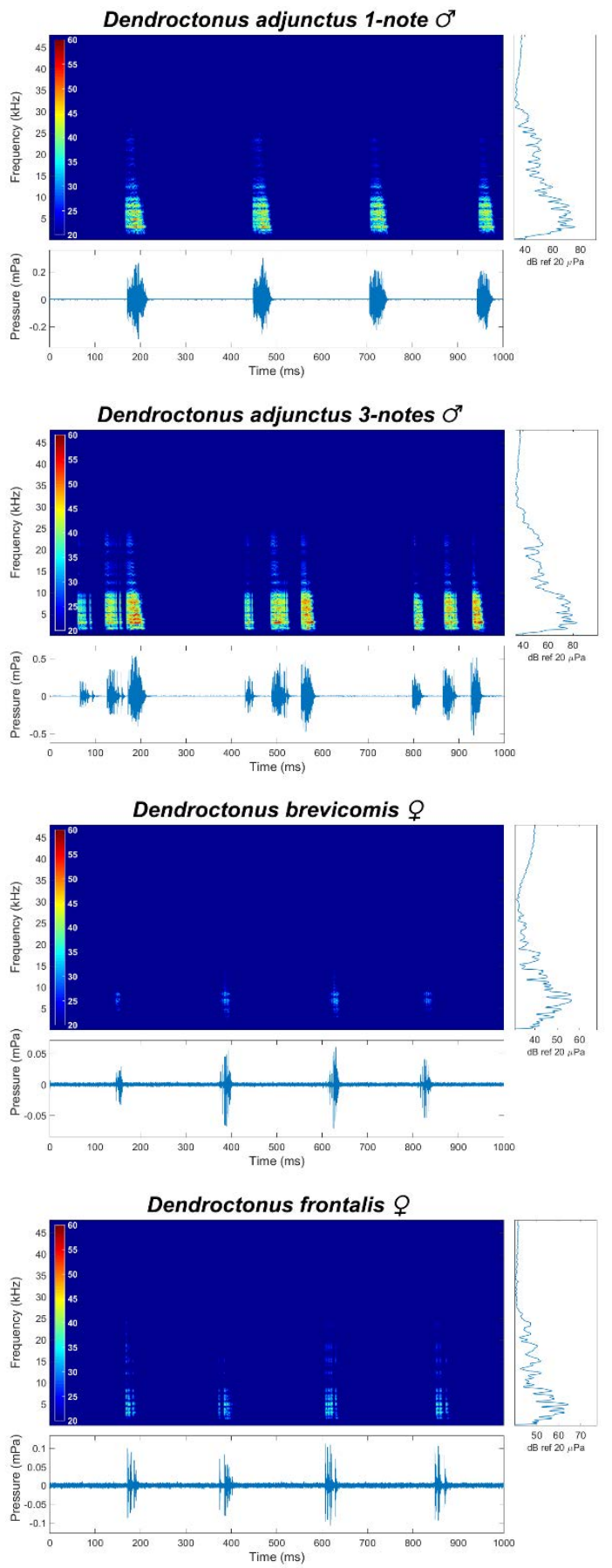
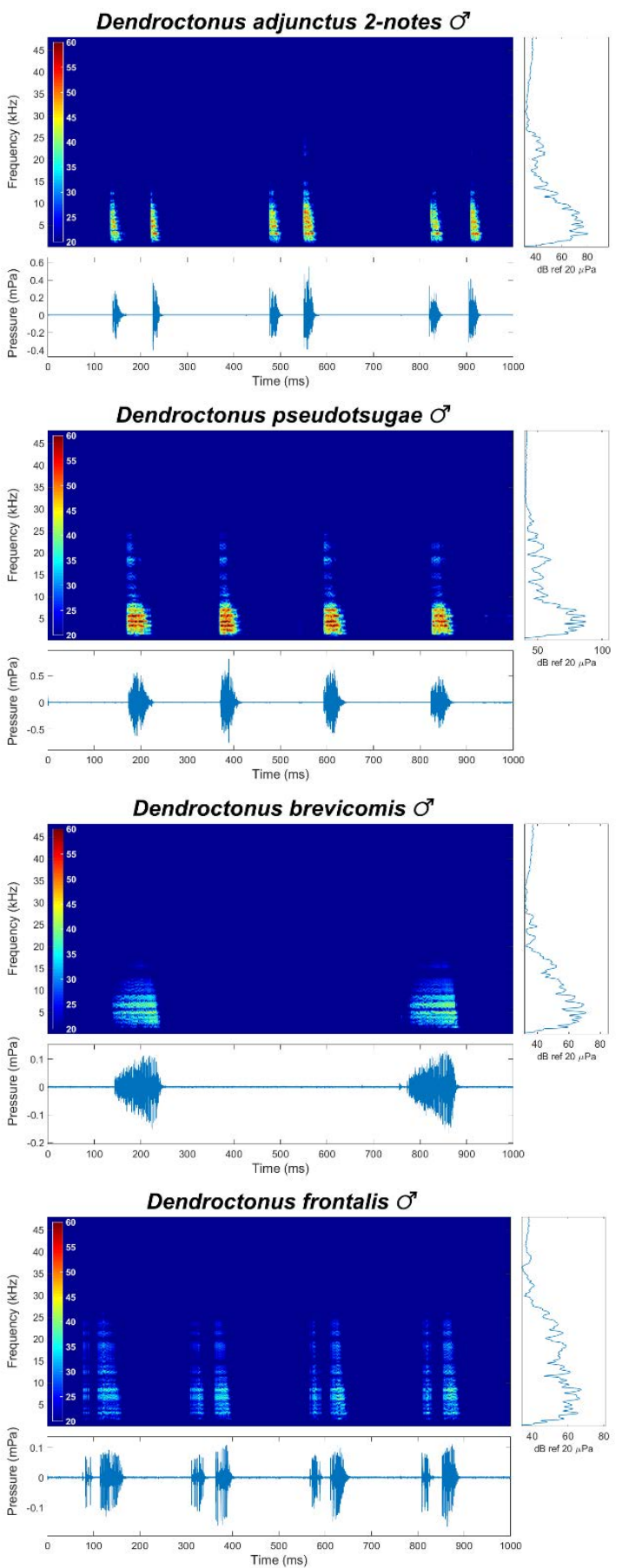

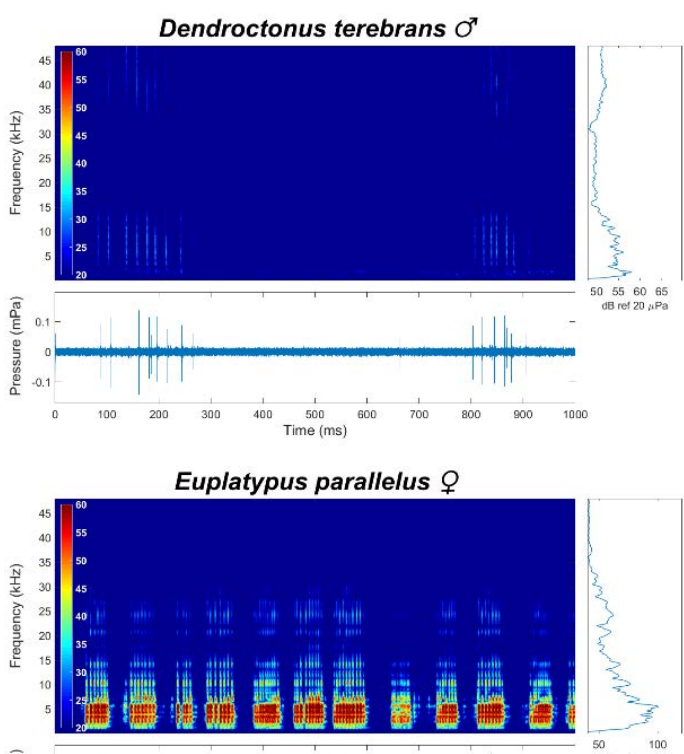

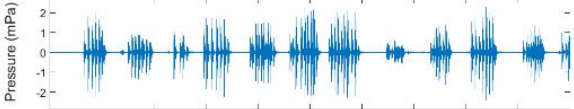

Hylesinus aculeatus $0^{7}$

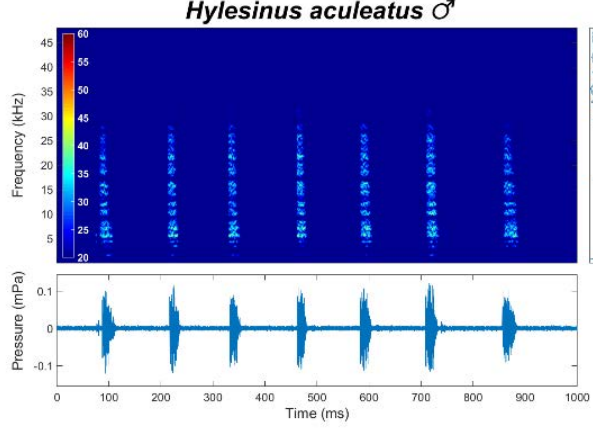

Hylurgus ligniperda $\sigma^{7}$

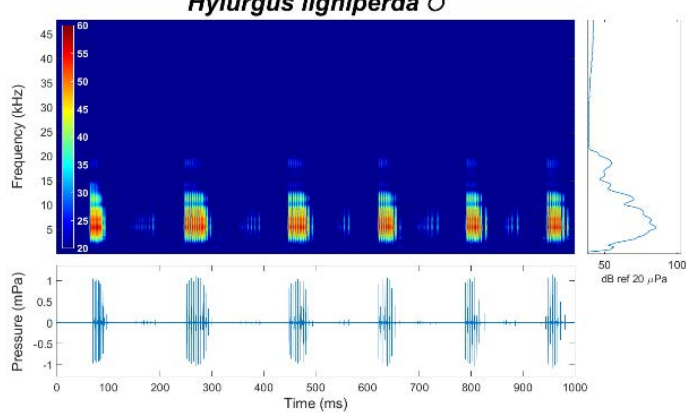

Ips calligraphus $O$

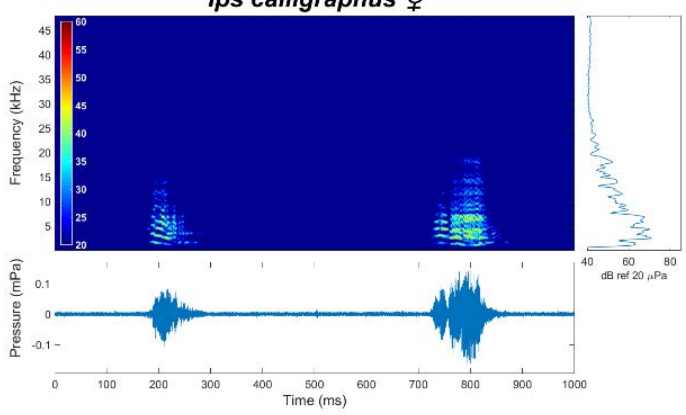

Hylastes ater $\mathrm{O}^{7}$

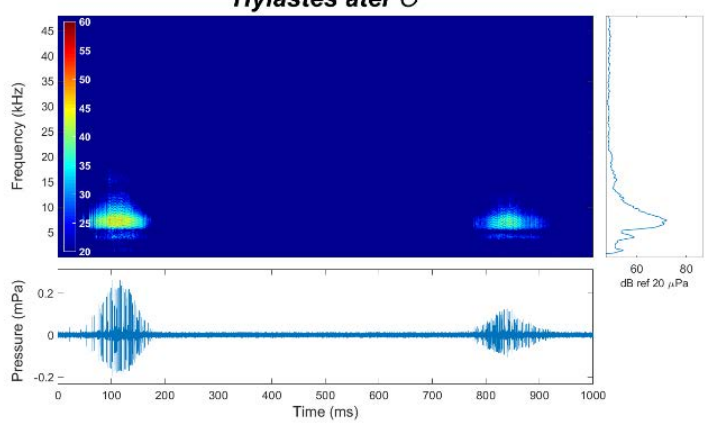

Euplatypus parallelus $0^{7}$

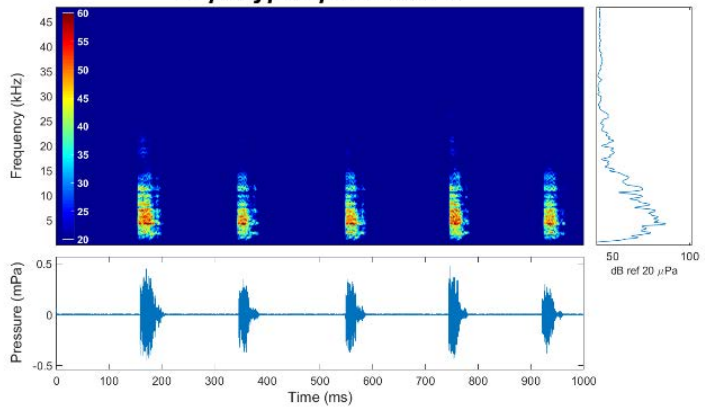

Hylurgops subcostulatus $O^{7}$

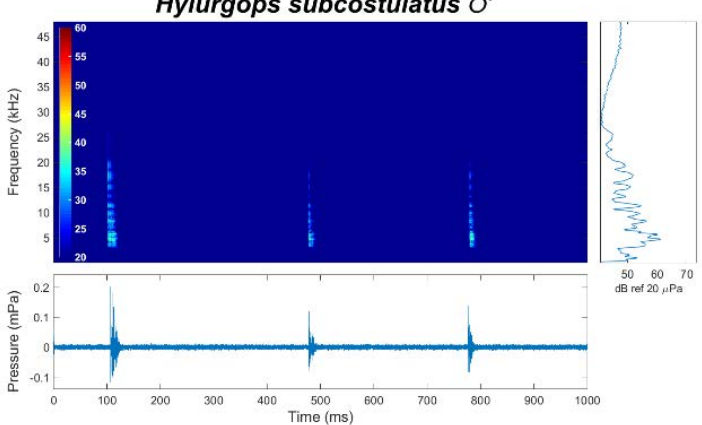

Ips avulsus $ᄋ$

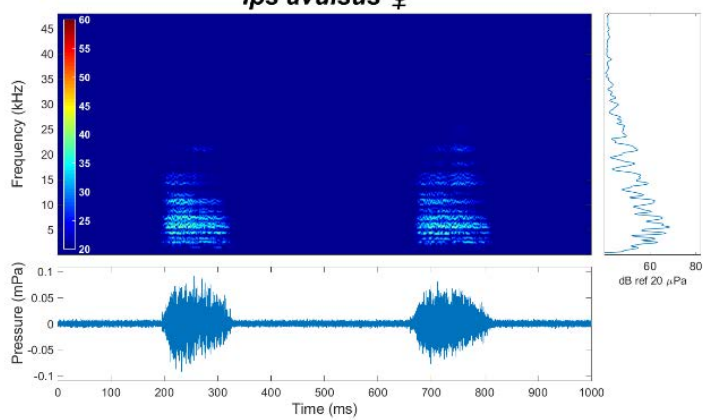

Ips grandicollis $ᄋ$

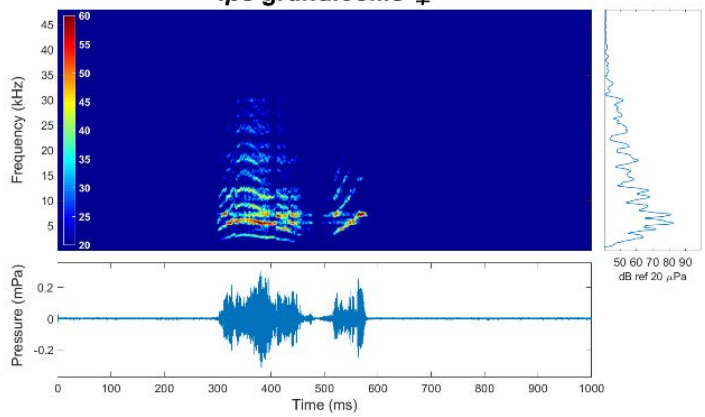



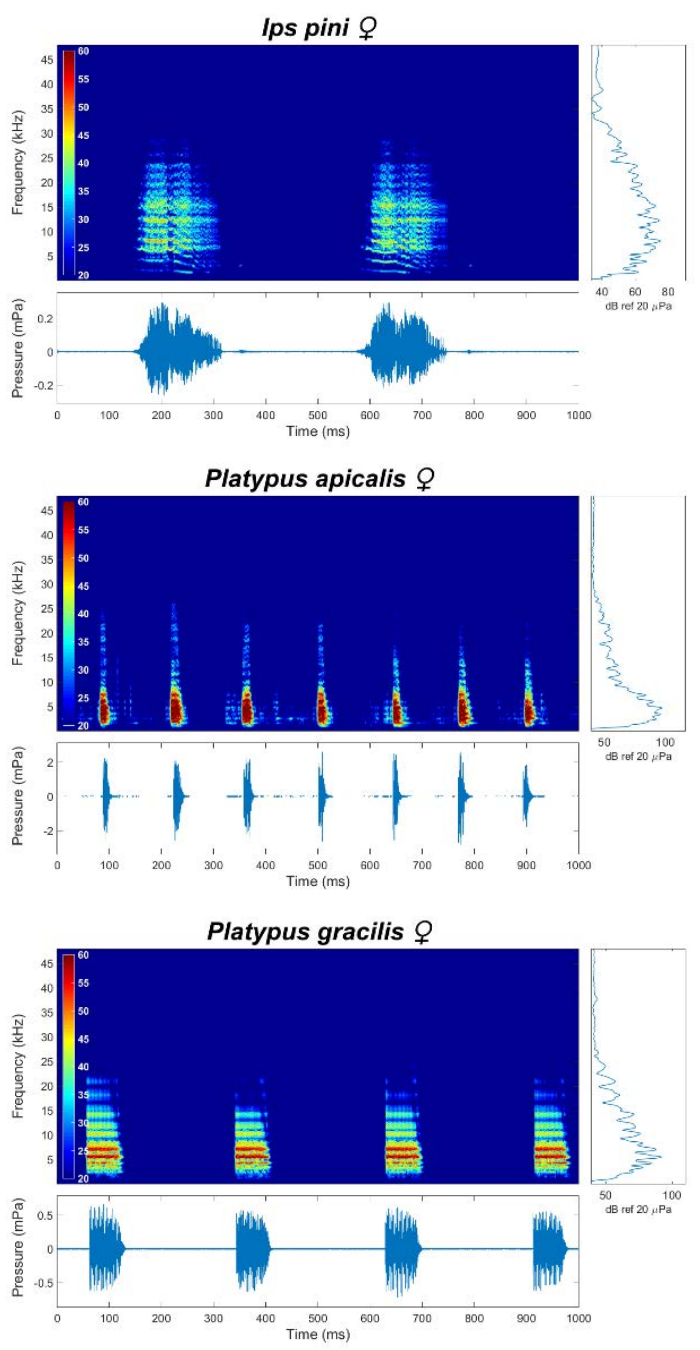

Scolytus ventralis $O$

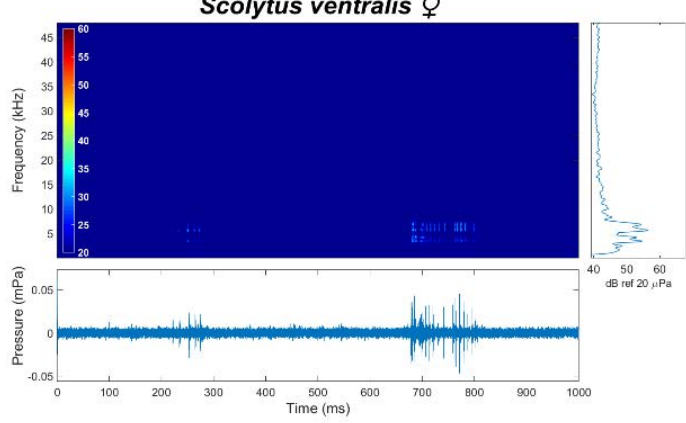

Treptoplatypus caviceps ${ }^{7}$

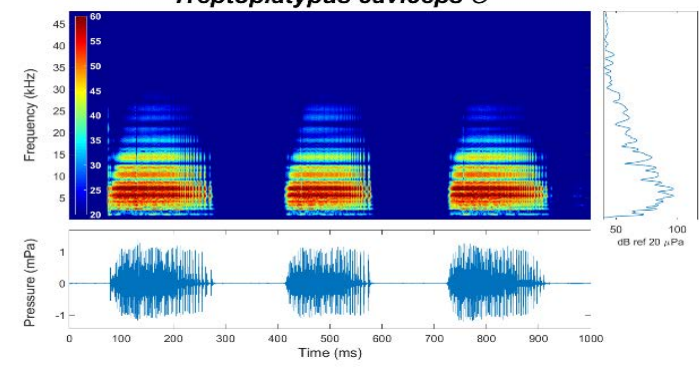

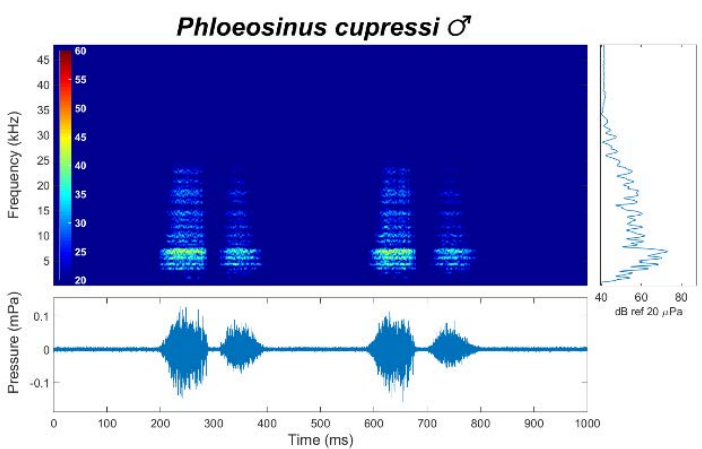
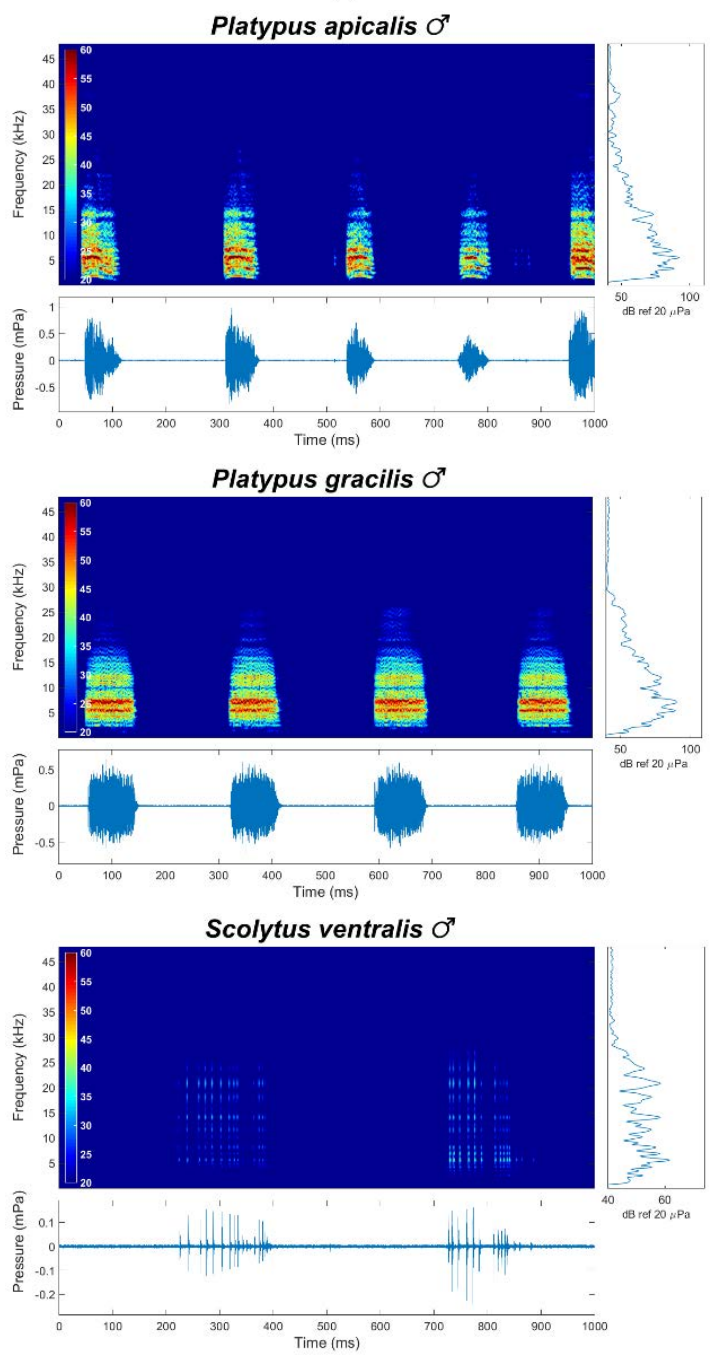